\title{
Linking Isotope Exchange with Fe(II)-Catalyzed Dissolution of Iron(hydr)oxides in the Presence of the Bacterial Siderophore Desferrioxamine-B
}

\author{
Jagannath Biswakarma, ${ }^{\dagger, \ddagger}$ Kyounglim Kang, ${ }^{\S}$ Walter D. C. Schenkeveld, ${ }^{\S, \perp \odot ~ S t e p h a n ~ M . ~ K r a e m e r, ~}{ }^{\S}$ \\ Janet G. Hering, ${ }^{\dagger,+, \|(0)}$ and Stephan J. Hug*, \\ ${ }^{\dagger}$ Eawag, Swiss Federal Institute of Aquatic Science and Technology, CH-8600 Dübendorf, Switzerland \\ ${ }^{\ddagger}$ Swiss Federal Institute of Technology (ETH) Zurich, IBP, CH-8092 Zürich, Switzerland \\ ${ }^{\S}$ Dept. of Environmental Geosciences, University of Vienna, 1090 Vienna, Austria \\ "Swiss Federal Institute of Technology Lausanne (EPFL), ENAC, CH-1015 Lausanne, Switzerland
}

Supporting Information

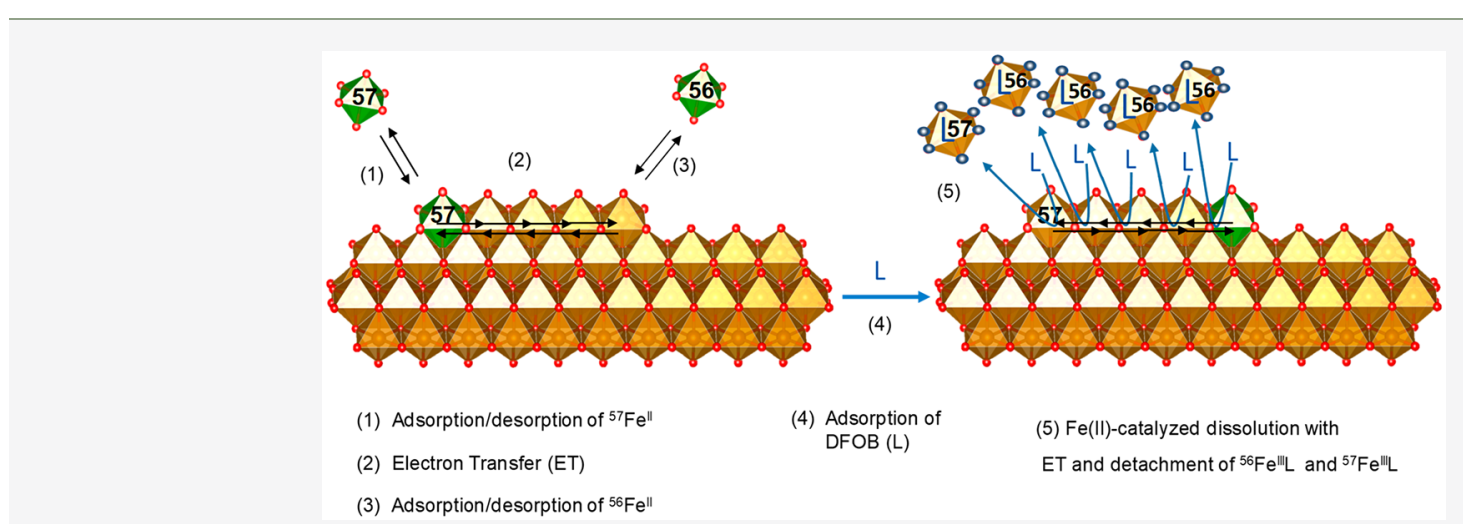

ABSTRACT: Dissolution of Fe(III) phases is a key process in making iron available to biota and in the mobilization of associated trace elements. Recently, we have demonstrated that submicromolar concentrations of Fe(II) significantly accelerate rates of ligand-controlled dissolution of $\mathrm{Fe}(\mathrm{III})$ (hydr)oxides at circumneutral $\mathrm{pH}$. Here, we extend this work by studying isotope exchange and dissolution with lepidocrocite $(\mathrm{Lp})$ and goethite $(\mathrm{Gt})$ in the presence of 20 or $50 \mu \mathrm{M}$ desferrioxamine-B (DFOB). Experiments with $\mathrm{Lp}$ at $\mathrm{pH} 7.0$ were conducted in carbonate-buffered suspensions to mimic environmental conditions. We applied a simple empirical model to determine dissolution rates and a more complex kinetic model that accounts for the observed isotope exchange and catalytic effect of $\mathrm{Fe}$ (II). The fate of added tracer ${ }^{57} \mathrm{Fe}$ (II) was strongly dependent on the order of addition of ${ }^{57} \mathrm{Fe}$ (II) and ligand. When DFOB was added first, tracer ${ }^{57} \mathrm{Fe}$ remained in solution. When ${ }^{57} \mathrm{Fe}$ (II) was added first, isotope exchange between surface and solution could be observed at $\mathrm{pH} 6.0$ but not at $\mathrm{pH} 7.0$ and 8.5 where ${ }^{57} \mathrm{Fe}$ (II) was almost completely adsorbed. During dissolution of Lp with DFOB, ratios of released ${ }^{56} \mathrm{Fe}$ and ${ }^{57} \mathrm{Fe}$ were largely independent of DFOB concentrations. In the absence of DFOB, addition of phenanthroline $30 \mathrm{~min}$ after tracer ${ }^{57} \mathrm{Fe}$ desorbed predominantly ${ }^{56} \mathrm{Fe}(\mathrm{II})$, indicating that electron transfer from adsorbed ${ }^{57} \mathrm{Fe}$ to ${ }^{56} \mathrm{Fe}$ of the Lp surface occurs on a time scale of minutes to hours. In contrast, comparable experiments with Gt desorbed predominantly ${ }^{57} \mathrm{Fe}$ (II), suggesting a longer time scale for electron transfer on the Gt surface. Our results show that addition of $1-5 \mu \mathrm{M} \mathrm{Fe}$ (II) leads to dynamic charge transfer between dissolved and adsorbed species and to isotope exchange at the surface, with the dissolution of Lp by ligands accelerated by up to 60 -fold.

\section{INTRODUCTION}

Iron (Fe) mobilization from poorly soluble $\mathrm{Fe}(\mathrm{III})$ phases by natural ligands (e.g., siderophores) is a key Fe acquisition strategy for organisms in Fe-deficient conditions. ${ }^{14}$ Siderophore-promoted dissolution rates of $\mathrm{Fe}(\mathrm{III})$ (oxyhydr)oxides have been reported to be slow at circumneutral $\mathrm{pH}$, but can be accelerated by synergistic effects of two or more ligands. ${ }^{15-21}$ For example, the dissolution rates of hematite, ${ }^{20,22}$ ferrihydrite, $^{23}$ and goethite with bacterial siderophore desferrioxamine-B (DFOB) were accelerated 2-10 times by addition of oxalate, ${ }^{15-17,21}$ Suwannee river fulvic acid, ${ }^{24}$ and ascorbate. ${ }^{20,25}$ The synergistic Fe mobilization was also observed in carbonate soils with ascorbate and siderophores. ${ }^{26}$

Very recently, we have demonstrated that, at circumneutral $\mathrm{pH}$, submicromolar concentrations of added Fe(II) signifi-

Received: July 15, 2019

Revised: December 15, 2019

Accepted: December 17, 2019

Published: December 17, 2019 
cantly accelerate dissolution rates of lepidocrocite (Lp), goethite (Gt), hematite, and ferrihydrite, with the synthetic ligands ethylenediaminetetraacetate (EDTA) and hydroxybenzyl ethylenediaminediacetic acid (HBED) and also with the bacterial siderophore desferrioxamine-B (DFOB). ${ }^{27,28}$ The catalytic effect (CE) of $\mathrm{Fe}$ (II) on the dissolution of $\mathrm{Lp}$ at $\mathrm{pH} 6$ with EDTA could be described by a kinetic model in which accelerated dissolution was attributed to electron transfer (ET) to surface $\mathrm{Fe}$ (III) followed by detachment of Fe(III)EDTA.

In other studies, recrystallization of $\mathrm{Fe}$ (III)(oxyhydr)oxide minerals observed in ${ }^{57} \mathrm{Fe}$ isotope tracer studies was attributed to adsorption of added ${ }^{57} \mathrm{Fe}$ (II) followed by interfacial ET and bulk conduction. ${ }^{29-33}$ Thus, during recrystallization, mineral growth occurs at the adsorption site and bulk ET leads to $\mathrm{Fe}(\mathrm{II})$ release at a distant site with zero net dissolution of the mineral. ${ }^{34-40}$ Although $\mathrm{Fe}(\mathrm{II})$ adsorption is $\mathrm{pH}$-dependent, the net interfacial ET per adsorbed $\mathrm{Fe}$ (II) was found to be independent of solution $\mathrm{pH} .{ }^{37,40}$

We included these processes in interpreting the release of ${ }^{57} \mathrm{Fe}$ at $\mathrm{pH} 6$ in our recent study of Lp dissolution with ${ }^{57} \mathrm{Fe}$ (II) and EDTA. ${ }^{27}$ In that study, however, we did not explicitly include isotope exchange in our kinetic model, nor did we quantify the ratio of ${ }^{57} \mathrm{Fe}$ release over ${ }^{56} \mathrm{Fe}$ release during dissolution. Here, we expand our previous work by examining isotopic exchange in greater detail at $\mathrm{pH}$ 6.0, 7.0, and 8.5 using the dissolution-promoting ligand DFOB. We use an empirical kinetic model to compare the rates of dissolution for the complete dissolution reaction with initial rates that we reported previously. ${ }^{28}$ We then apply an expanded mechanistic kinetic model to describe isotopic exchange before and during $\mathrm{Lp}$ dissolution in the presence and absence of DFOB at $\mathrm{pH} 6.0$ and 7.0. We also conducted some experiments with $\mathrm{Gt}$ to assess the effect of the solids (Gt and Lp) on the fate of added ${ }^{57} \mathrm{Fe}(\mathrm{II})$. Finally, we conducted experiments with both Lp and $\mathrm{Gt}$ in which we added phenanthroline (phen) to desorb Fe(II) and to examine isotopic exchange in the absence of dissolution.

\section{MATERIALS AND METHODS}

Chemicals and Solutions. Aqueous solutions were prepared using high-purity doubly deionized (DDI) water (Barnstead Nanopure, $>18 \mathrm{M} \Omega \mathrm{cm}$ ). All chemicals used were of analytical grade and are listed in the Supporting Information (SI) (Table S1). The detailed synthesis procedure and characterization of $\mathrm{Lp}$ and Gt were described in our recent studies. $^{27,28}$ Surface areas as measured by Brunauer-EmmettTeller (BET) were $63 \mathrm{~m}^{2} \mathrm{~g}^{-1}$ for Lp and $105 \mathrm{~m}^{2} \mathrm{~g}^{-1}$ for Gt. A $20 \mathrm{mM}{ }^{57} \mathrm{Fe}$ (II) stock solution was prepared by dissolving 5.7 $\mathrm{mg}$ of ${ }^{57} \mathrm{Fe}$ (Sigma-Aldrich, $99 \%$ pure in $\mathrm{Fe}$, with an isotopic composition of $95.06 \%{ }^{57} \mathrm{Fe}, 3.04 \%{ }^{56} \mathrm{Fe}$, and $1.86 \%{ }^{58} \mathrm{Fe}$ ) in $100 \mu \mathrm{L}$ of $2.5 \mathrm{M} \mathrm{HCl}$ at $50-60{ }^{\circ} \mathrm{C}$ for $4 \mathrm{~h}$ and dilution to 5.00 $\mathrm{mL}$ with DDI $\mathrm{H}_{2} \mathrm{O}$ for conducting studies on isotope exchange and dissolution. The final concentration of $\mathrm{Fe}(\mathrm{II})$ was verified colorimetrically with phen, and the concentration of ${ }^{57} \mathrm{Fe}$ with inductively coupled plasma-mass spectrometry (ICP-MS). Both concentrations were $20 \pm 1 \mathrm{mM}$ (standard deviation of triplicate measurements).

Iron(hydr)oxide Dissolution in Batch Experiments with DFOB and $\mathrm{Fe}(\mathrm{II})$ or ${ }^{57} \mathrm{Fe}(\mathrm{II})$. Batch dissolution experiments were conducted under anoxic conditions at room temperature $\left(22-24{ }^{\circ} \mathrm{C}\right)$ with suspensions of 1125 $\mu \mathrm{M}\left(=0.1 \mathrm{~g} \mathrm{~L}^{-1}\right) \mathrm{Lp}$ or $\mathrm{Gt}, 20$ or $50 \mu \mathrm{M} \mathrm{DFOB}$, and varied concentrations of $\mathrm{Fe}(\mathrm{II})(1,2$, and $5 \mu \mathrm{M})$. Isotope experiments were conducted with $2 \mu \mathrm{M}{ }^{57} \mathrm{Fe}(\mathrm{II})$. Most experiments were conducted at $\mathrm{pH} 7.0$ in $3 \mathrm{mM} \mathrm{NaHCO}$ solution, purged with a high-purity gas mixture of $2 \% \mathrm{CO}_{2}$ in $\mathrm{N}_{2}$. Additional experiments were conducted at $\mathrm{pH} 6.0 \quad(5 \mathrm{mM} 2-(\mathrm{N}-$ morpholino)ethanesulfonic acid (MES)), pH 7.0 (5 mM 3( $N$-morpholino)propanesulfonic acid (MOPS)), and $\mathrm{pH} 8.5$ (5 mM piperazine- $N, N^{\prime}$-bis(2-ethanesulfonic acid) (PIPES)), with $9.5 \mathrm{mM} \mathrm{NaCl}$ as inert electrolyte. In the series of connected experiments with different $\mathrm{Fe}$ (II) concentrations, each experiment was conducted once. All ${ }^{57} \mathrm{Fe}$ (II) isotope experiments were conducted in duplicate. Specifics of the conditions for all experiments are summarized in Table S2.

Briefly, suspensions were prepared by dispersing $10 \mathrm{mg}$ of $\mathrm{Lp}$ or $\mathrm{Gt}$ in $100 \mathrm{~mL}$ of aqueous solution. The $130 \mathrm{~mL}$ reaction flasks were sonicated for $10-15 \mathrm{~min}$ to obtain homogeneous suspensions. All suspensions were purged with high-purity $\mathrm{N}_{2}$ (either with or without $2 \% \mathrm{CO}_{2}$ ) for at least $3 \mathrm{~h}$ before initiation of the experiments $(t=0)$. After dissolved $\mathrm{O}_{2}$ concentrations dropped to below $20 \mathrm{nM}$ (monitored with a PreSens Fibox 4 trace oxygen sensor), experiments were started by addition of small volumes of $\mathrm{N}_{2}$-purged stock solutions to reach 20 or $50 \mu \mathrm{M}$ DFOB and $0-5 \mu \mathrm{M} \mathrm{Fe}$ (II). In one set of experiments, $\mathrm{Fe}$ (II) was added first, followed by addition of DFOB after $1800 \mathrm{~s}$; in a second set, DFOB was added first, followed by addition of $\mathrm{Fe}$ (II) after $1800 \mathrm{~s}$. Samples $(2 \mathrm{~mL})$ were drawn periodically, filtered through 0.1 $\mu \mathrm{m}$ nylon filters (Whatman Puradisc 13 syringe filters), and diluted in $1 \% \mathrm{HNO}_{3}$ (Merck, suprapure) for inductively coupled plasma-mass spectrometry (ICP-MS, Agilent $7500 \mathrm{cx}$ ) analysis. The dissolved $\mathrm{Fe}$ concentrations ([Fe $\left.]_{\text {diss. }}\right)$ were measured with repeated ICP-MS measurements. At the applied concentrations of up to $5 \mu \mathrm{M} \mathrm{Fe}(\mathrm{II})$, our solutions and suspension were not oversaturated with respect to $\mathrm{FeCO}_{3}$ (siderite), as shown with speciation calculations in Figure $\mathrm{S} 1$ in the SI.

Isotope Exchange and Dissolution. To investigate the fate of added $\mathrm{Fe}(\mathrm{II})$, we added ${ }^{57} \mathrm{Fe}$ (II) as a tracer $1800 \mathrm{~s}$ before or after DFOB addition to $\mathrm{Lp}$ or Gt suspension. Mineral dissolution was followed by measuring the concentration of dissolved iron $\left(\left[{ }^{56} \mathrm{Fe}\right]{ }^{*}\right.$ diss. $)$ with ICP-MS at mass 56 , calibrated to represent the concentration of the total natural abundance iron $\left(5.85 \%{ }^{54} \mathrm{Fe}, 91.75 \%{ }^{56} \mathrm{Fe}, 2.12 \%{ }^{57} \mathrm{Fe}, 0.28 \%{ }^{58} \mathrm{Fe}\right)$. This is the concentration of $\mathrm{Fe}$ released from the solid during isotope exchange and dissolution.

The dissolved concentration of ${ }^{57} \mathrm{Fe}\left(\left[{ }^{57} \mathrm{Fe}\right]_{\text {diss }}\right)$ was measured with ICP-MS at mass 57. The concentration of ${ }^{57} \mathrm{Fe}$ released from the solid during isotope exchange and dissolution $\left(0.0212\left[{ }^{56} \mathrm{Fe}\right]{ }_{\text {diss }}\right)$ was subtracted from $\left[{ }^{57} \mathrm{Fe}\right]_{\text {diss. }}$ to obtain the dissolved concentration of tracer ${ }^{57} \mathrm{Fe}$ $\left(\left[{ }^{57} \mathrm{Fe}\right]_{\text {tracer,diss. }}\right)$.

Isotope Exchange without Net Dissolution. To assess isotopic exchange at $\mathrm{pH} 7.0$ without net dissolution, we added phen $(100 \mu \mathrm{M}) 1800 \mathrm{~s}$ after ${ }^{57} \mathrm{Fe}$ (II) $(2 \mu \mathrm{M})$ addition to Lp or Gt suspension. Phen complexes over $99.9 \%$ of dissolved Fe(II) as $\mathrm{Fe}(\mathrm{II})$ (phen) ${ }_{3}{ }^{2+}$ (Figure S2). In control experiments, phen did not lead to dissolution of $\mathrm{Lp}$, and $\mathrm{Fe}(\mathrm{II})$ (phen) ${ }_{3}{ }^{2+}$ formed by addition of $\mathrm{Fe}(\mathrm{II})$ to an $\mathrm{Lp}$ suspension containing $100 \mu \mathrm{M}$ phen did not, or only very, weakly adsorb to the surface of $\mathrm{Lp}$ (Figures S3 and S4). After desorption of Fe(II) with phen, dissolved concentrations of ${ }^{57} \mathrm{Fe}$ and ${ }^{56} \mathrm{Fe}$ were measured with ICP-MS.

Kinetic Modeling. In the present work and our previous studies, we have used a variety of approaches for kinetic 
modeling: (i) empirical modeling based on initial dissolution rates, ${ }^{28}$ (ii) empirical modeling based on the full time course of dissolution (this work), and (iii) detailed mechanistic modeling (both this and previous work ${ }^{27}$ ).

Empirical modeling of $\mathrm{Lp}$ dissolution at $\mathrm{pH} 7.0$ with $\mathrm{Fe}$ (II) added $1800 \mathrm{~s}$ after 20 or $50 \mu \mathrm{M}$ DFOB was conducted to describe the full time course of the experimentally measured dissolved $\mathrm{Fe}$ concentrations. We applied a pseudo-first-order model that assumes that the rate of $\mathrm{Fe}(\mathrm{II})$-catalyzed dissolution $\left(R_{\mathrm{C}}\right)$ is proportional to the free ligand concentration $[\mathrm{L}]$ in the solution and the concentration of added $\mathrm{Fe}(\mathrm{II})$. In short, the increase in $[\mathrm{Fe}]_{\text {diss. }}$ over time is expressed in terms of a rate law with a single adjustable rate coefficient $k_{\mathrm{C} \text {,app }}\left[\mathrm{s}^{-1} \mathrm{M}^{-1}\right]$, the concentration of added $\mathrm{Fe}(\mathrm{II})$, and the ligand concentration. The reaction rate decreases as $[\mathrm{Fe}]_{\text {diss. }}$ approaches the concentration of initially added ligand $[\mathrm{L}]_{0}$

$$
R_{\mathrm{C}}=\frac{\mathrm{d}[\mathrm{Fe}]_{\text {diss. }}}{\mathrm{d} t}=[\mathrm{Fe}(\mathrm{II})] \cdot k_{\mathrm{C}, \text { app }} \cdot\left([\mathrm{L}]_{0}-[\mathrm{Fe}]_{\text {diss. }, t}\right)
$$

To calculate $[\mathrm{Fe}]_{\text {diss }}$ as a function of time, we used the integrated form

$$
[\mathrm{Fe}]_{\text {diss. }, t}=[\mathrm{Fe}]_{\text {diss. }, t_{1}}+[\mathrm{L}]_{t_{1}} \cdot\left(1-\mathrm{e}^{-\left(t-t_{1}\right) \cdot k_{\mathrm{C}, \text { app }} \cdot[\mathrm{Fe}(\mathrm{II})]}\right)
$$

where $t_{1}$ is the time of $\mathrm{Fe}(\mathrm{II})$ addition (between 1800 and $1920 \mathrm{~s}) .[\mathrm{Fe}]_{\text {diss. } t_{1}}$ is the concentration of dissolved Fe at $t_{1}$ including the concentration of added $\mathrm{Fe}(\mathrm{II}) .[\mathrm{L}]_{t_{1}}$ is the free ligand concentration at $t_{1}\left([\mathrm{~L}]_{0}-[\mathrm{Fe}]_{\text {diss. } t_{1}}\right)$. Note that, in this model, the contribution of the noncatalyzed dissolution rate $\left(R_{\mathrm{L}}\right)$ after the addition of $\mathrm{Fe}(\mathrm{II})$ is assumed to be negligible in comparison to $R_{\mathrm{C}}$.

For detailed mechanistic kinetic modeling, we used the kinetic program ACUCHEM ${ }^{41}$ and MATLAB (MATLAB, MathWorks, Inc., Natick, Massachusetts, www.mathworks. com). The model was used to determine whether the proposed mechanisms (i.e., reactions included in the model) could explain the measured data including isotope exchange. The Nelder Mead Simplex Optimization routine in MATLAB was applied to optimize the rate coefficients of rate-determining reactions by minimization of the sum of squared differences between measured data points and model output for several experiments simultaneously.

\section{RESULTS AND DISCUSSION}

Dissolution of Lp in a Carbonate Buffer. Dissolution experiments were conducted with $\mathrm{Lp}(1125 \mu \mathrm{M})$ at $\mathrm{pH} 7.0$ in a carbonate buffer for comparison with previous studies in MOPS buffer and to compare previously reported initial dissolution rates ${ }^{28}$ with rates describing the full course of the dissolution reaction. As shown in Figure 1, addition of either 20 or $50 \mu \mathrm{M}$ DFOB alone (gray diamonds) resulted in only a very slow increase of dissolved $\mathrm{Fe}$ concentrations $\left([\mathrm{Fe}]_{\text {diss. }}\right)$ over time. In experiments where $1-5 \mu \mathrm{M} F($ II) was added after DFOB, accelerated dissolution was observed. Note that the time interval between addition of the two reactants, here DFOB first followed by $\mathrm{Fe}$ (II), was always $1800 \mathrm{~s}$.

Because of the low solubility of $\mathrm{Fe}$ (III) at $\mathrm{pH} 7$, dissolved $\mathrm{Fe}$ measured in the Lp suspensions can be assumed to be $\mathrm{Fe}$ (III) complexed by DFOB. The extent of $\mathrm{Lp}$ dissolution is ultimately limited by the total ligand concentration $\left([\mathrm{L}]_{\mathrm{T}}\right)$. With addition of $5 \mu \mathrm{M} \mathrm{Fe}(\mathrm{II}),[\mathrm{Fe}]_{\text {diss. }}$ (green squares) increased rapidly, indicating accelerated dissolution, and
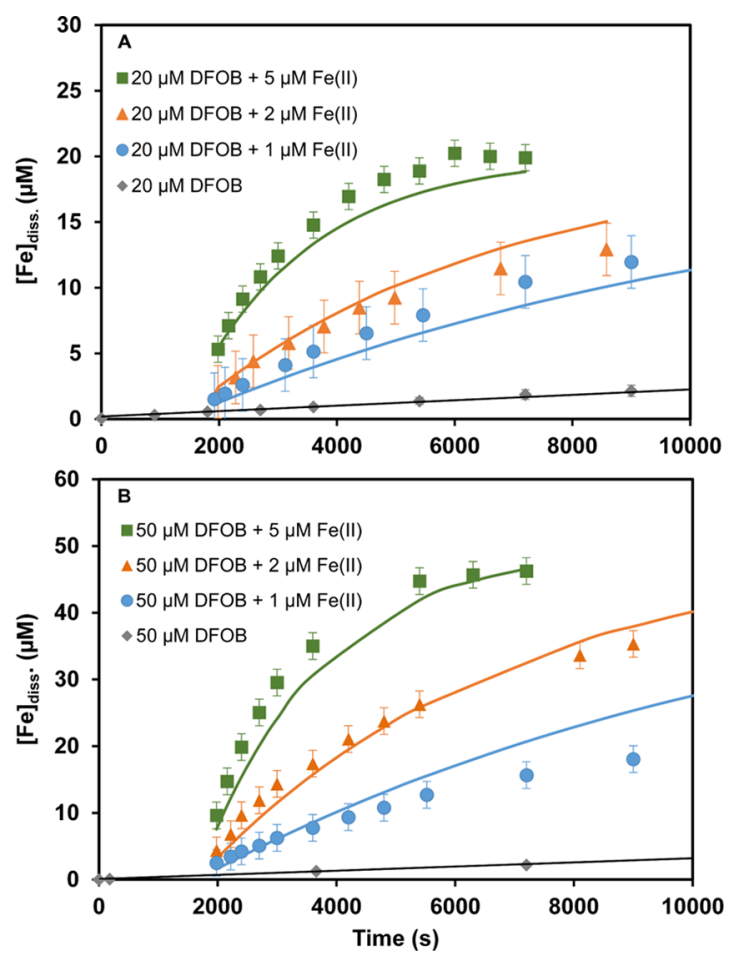

Figure 1. Lepidocrocite (Lp) dissolution after addition of $\mathrm{Fe}(\mathrm{II})$ to an Lp suspension $(1125 \mu \mathrm{M})$ in the presence of (A) $20 \mu \mathrm{M}$ DFOB and (B) $50 \mu \mathrm{M}$ DFOB, under anoxic conditions at $\mathrm{pH} 7.0$ (carbonatebuffered). The error bars correspond to the standard deviations of ICP-MS measurements obtained from repeated calibrations. Fe(II) was added $1800 \mathrm{~s}$ after DFOB addition. The solid lines represent empirical model fits.

reached a plateau within $8000 \mathrm{~s}$ at values approaching the total concentration of DFOB (i.e., $20 \mu \mathrm{M}$ in Figure $1 \mathrm{~A}$ and 50 $\mu \mathrm{M}$ in Figure $1 \mathrm{~B})$. At lower added $\mathrm{Fe}(\mathrm{II})$ concentrations of 1 or $2 \mu \mathrm{M}$, Lp dissolution proceeded more slowly (blue circles and orange triangles) and did not reach a plateau within the experimental timeframe.

An empirical kinetic model with a single adjustable parameter $k_{\mathrm{C} \text {,app }}\left[\mathrm{s}^{-1}\right]$ (see Kinetic Modeling in the Materials and Methods section) is sufficient to describe the full time course of the dissolution experiments at both DFOB concentrations and all three concentrations of added $\mathrm{Fe}(\mathrm{II})$. The fits to this empirical model are shown by the solid lines in Figure 1. The simple rate expression (2) leads to adequate fits to the experimentally determined concentrations with the optimized value for $k_{\mathrm{C} \text {,app }}$ of $93 \mathrm{M}^{-1} \mathrm{~s}^{-1}$.

This empirical model provides a basis for comparison with the observations reported in our previous study conducted in MOPS buffer. In that study, we defined catalytic effect (CE) as the ratio of $R_{\mathrm{C}}$ to $R_{\mathrm{L}}$, where, in both cases, the reaction was far from completion. (For the definitions of $R_{\mathrm{C}}$ and $R_{\mathrm{L}}$, see Kinetic Modeling in the Materials and Methods section.) The comparison of $\mathrm{CE}$ values derived from the current study and those reported previously shows that $\mathrm{CE}$ is larger in carbonatethan in MOPS-buffered systems (Table 1 and Figure S5). This might be explained by more adsorption of $\mathrm{Fe}(\mathrm{II})$ in the presence of carbonate, which forms negatively charged innersphere surface complexes. ${ }^{42}$ In a study of the oxidation of adsorbed $\mathrm{Fe}(\mathrm{II})$ by $\mathrm{CCl}_{4}{ }^{43} \mathrm{Fe}(\mathrm{II})$ adsorption on $\mathrm{Gt}$ was reported to be slightly lower in Good's buffer than in a carbonate buffer. Faster and more complete adsorption of 
Table 1. Dissolution Rates of Lepidocrocite and Catalytic Effect of Fe(II), in the Presence of DFOB (20 or $50 \mu \mathrm{M})$ with Varied $\mathrm{Fe}\left(\right.$ II) Concentrations ${ }^{b}$

\begin{tabular}{|c|c|c|c|c|c|}
\hline \multirow[b]{2}{*}{ experiments } & \multirow[b]{2}{*}[\mathrm{Fe}(\mathrm{II})]{$(\mu \mathrm{M})$} & \multicolumn{2}{|c|}{$\begin{array}{l}\text { rate of dissolution }{ }^{a} R_{\mathrm{C}} \text {, and } \\
R_{\mathrm{L}}(\text { for }[\mathrm{FeII}]=0 \mu \mathrm{M})\end{array}$} & \multirow[b]{2}{*}{ catalytic effect $R_{\mathrm{C}} / R_{\mathrm{L}}$} & \multirow[b]{2}{*}{ buffers $(\mathrm{pH})$} \\
\hline & & $\left(\mathrm{nM} \mathrm{s}^{-1}\right)$ & $\left(\mathrm{nmol} \mathrm{s}{ }^{-1} \mathrm{~m}^{-2}\right)$ & & \\
\hline $20 \mu \mathrm{M}$ DFOB & 0 & 0.25 & 0.04 & 1 & carbonate $(\mathrm{pH} \mathrm{7.0)}$ \\
\hline $20 \mu \mathrm{M}$ DFOB $+1 \mu \mathrm{M} \mathrm{Fe}(\mathrm{II})$ & 1 & 1.71 & 0.27 & 7 & \\
\hline $20 \mu \mathrm{M} \mathrm{DFOB}+2 \mu \mathrm{M}$ Fe(II) & 2 & 3.24 & 0.51 & 13 & \\
\hline $20 \mu \mathrm{M}$ DFOB $+5 \mu \mathrm{M}$ Fe(II) & 5 & 6.70 & 1.06 & 27 & \\
\hline $20 \mu \mathrm{M}$ DFOB & 0 & & 0.07 & 1 & MOPS (pH 7.0) (Kang et al., 2019) \\
\hline $20 \mu \mathrm{M}$ DFOB $+2 \mu \mathrm{M} F($ II $)$ & 2 & & 0.29 & 4 & \\
\hline $50 \mu \mathrm{M}$ DFOB & 0 & 0.34 & 0.05 & 1 & carbonate $(\mathrm{pH} 7.0)$ \\
\hline $50 \mu \mathrm{M} \mathrm{DFOB}+1 \mu \mathrm{M} \mathrm{Fe}(\mathrm{II})$ & 1 & 4.50 & 0.71 & 13 & \\
\hline $50 \mu \mathrm{M}$ DFOB $+2 \mu \mathrm{M} \mathrm{Fe}(\mathrm{II})$ & 2 & 8.79 & 1.40 & 26 & \\
\hline $50 \mu \mathrm{M}$ DFOB $+5 \mu \mathrm{M} F($ II $)$ & 5 & 20.6 & 3.18 & 60 & \\
\hline $50 \mu \mathrm{M}$ DFOB & 0 & 0.20 & 0.03 & 1 & MOPS (pH 7.0) \\
\hline $50 \mu \mathrm{M}$ DFOB $+2 \mu \mathrm{M}{ }^{57} \mathrm{Fe}(\mathrm{II})$ & 2 & 2.03 & 0.32 & 10 & \\
\hline $50 \mu \mathrm{M}$ DFOB & 0 & 0.47 & 0.08 & 1 & PIPES (pH 8.5) \\
\hline $50 \mu \mathrm{M}$ DFOB $+2 \mu \mathrm{M}{ }^{57} \mathrm{Fe}(\mathrm{II})$ & 2 & 0.94 & 0.15 & 2 & \\
\hline
\end{tabular}

${ }^{a_{T}}$ The reported rates of accelerated dissolution were calculated at $t_{1}$, by applying eq 1 . There was no significant difference in rates when Fe(II) or ${ }^{57} \mathrm{Fe}$ (II) was added. The order of addition of $\mathrm{Fe}$ (II) (i.e., before or after DFOB addition) had no significant effect on dissolution rates. The rates of the noncatalyzed dissolution (i.e., ligand alone; $R_{\mathrm{L}}$ ) were determined from fits to the data without addition of Fe(II). ${ }^{b}$ Reported dissolution rates from Kang et al. (2019) were used to compare with the empirical model fits to the measured data of this study. The catalytic effect is defined as the ratio of the rate of dissolution in the presence of ligand to $\mathrm{Fe}(\mathrm{II})$ over the rate of dissolution in the presence of the ligand alone.

$\mathrm{Fe}(\mathrm{II})$ with carbonate compared to MOPS was also observed experimentally, as shown in Figures S5B, S6A, and S6B.

${ }^{57} \mathrm{Fe}$ Isotope Exchange and Lp Dissolution. The use of ${ }^{57} \mathrm{Fe}$ as an isotopic tracer provides additional insight into the process of accelerated Lp dissolution. Experiments were conducted at $\mathrm{pH} 6.0$ (MES), 7.0 (carbonate and MOPS), and 8.5 (PIPES) with $2 \mu \mathrm{M}{ }^{57} \mathrm{Fe}$ (II) and 20 or $50 \mu \mathrm{M}$ DFOB. The order of addition of ${ }^{57} \mathrm{Fe}$ (II) and DFOB was varied with one reactant added $1800 \mathrm{~s}$ before the other. In all cases, rapid increase of $\left[{ }^{56} \mathrm{Fe}\right]{ }_{\text {diss. }}$, corresponding to the natural abundance $\mathrm{Fe}$ released from Lp (shown as triangles in Figure 2), was observed only after both $\mathrm{Fe}$ (II) and DFOB had been added, without regard to the order of addition. In contrast, the order of addition of $\mathrm{Fe}$ (II) and DFOB did have a significant effect on the time course of the dissolved concentrations of tracer ${ }^{57} \mathrm{Fe}$ $\left(\left[{ }^{57} \mathrm{Fe}\right]_{\text {tracer,diss. }}\right)$ shown as the open and closed squares in Figure 2.

${ }^{57} \mathrm{Fe}$ (II) Added First. When ${ }^{57} \mathrm{Fe}$ (II) was added first (i.e., before DFOB), $\left[{ }^{57} \mathrm{Fe}\right]_{\text {tracer,diss. }}$ (solid orange squares) decreased over time at $\mathrm{pH} 6.0$ and was nearly or completely undetectable at $\mathrm{pH} 7.0$ and 8.5. At $\mathrm{pH}$ 6.0 (Figure 2A), a concurrent increase in $\left[{ }^{56} \mathrm{Fe}\right]^{*}{ }_{\text {diss. }}$ (red filled triangles) was observed. The sum of $\left[{ }^{57} \mathrm{Fe}\right]_{\text {tracer,diss }}$ and $\left[{ }^{56} \mathrm{Fe}\right]{ }^{*}$ diss. (green circles) corresponds to the added ${ }^{57} \mathrm{Fe}(\mathrm{II})$ concentration $(2.0 \mu \mathrm{M})$ at $t=0$ and then decreases (over $1800 \mathrm{~s}$ ) by $20 \%$. This suggests that some of the added ${ }^{57} \mathrm{Fe}$ (II) is immediately adsorbed to the surface and undergoes isotopic exchange with surface-bound $\mathrm{Fe}(\mathrm{III})$, resulting in detectable concentrations of dissolved ${ }^{56} \mathrm{Fe}$, which is presumably still in the +II oxidation state. Further adsorption appears to occur more slowly and also to be accompanied by isotopic exchange. These observations agree with our previously reported findings with ${ }^{57} \mathrm{Fe}(\mathrm{II})$ and $\mathrm{Lp}^{27}$ and with studies on isotope exchange with $\mathrm{Gt}^{33,37}$ and hematite. $^{32,38}$ At pH 7.0 (Figure 2B) and 8.5 (Figure 2C), $\left[{ }^{56} \mathrm{Fe}\right]{ }_{\text {diss }}$. was nearly or completely undetectable (i.e., before DFOB addition). This is consistent with the immediate and (nearly) complete loss of tracer ${ }^{57} \mathrm{Fe}$ (II) from solution at these $\mathrm{pH}$ values.

Upon addition of $50 \mu \mathrm{M}$ DFOB, accelerated dissolution, shown by increasing $\left[{ }^{56} \mathrm{Fe}\right]{ }^{*}{ }_{\text {diss. }}$ (filled purple triangles) over time, was observed at all $\mathrm{pH}$ values. $\mathrm{Lp}$ dissolution was more rapid and proceeded further toward completion at $\mathrm{pH} 7.0$ than at either $\mathrm{pH} 6.0$ or 8.5 , in agreement with our previous findings. ${ }^{28}$ In all cases, between $50 \%(\mathrm{pH} 8.5)$ and $85 \%(\mathrm{pH}$ 7.0 ) of the ${ }^{57} \mathrm{Fe}$ tracer was released back into solution by the end of the experiment.

DFOB Added First. As already discussed for the results shown in Figure 1, addition of DFOB alone causes only very slow Lp dissolution. Upon addition of ${ }^{57} \mathrm{Fe}(\mathrm{II})$, increasing $\left[{ }^{56} \mathrm{Fe}\right]{ }_{\text {diss. }}$ (empty purple triangles) was observed over time. The overlap of filled and empty purple triangles in Figure 2B indicate that the order of ${ }^{57} \mathrm{Fe}$ (II) and $\mathrm{DFOB}$ addition did not significantly affect the rate of accelerated Lp dissolution. In contrast, the behavior of the ${ }^{57} \mathrm{Fe}$ (II) tracer was distinctly different when DFOB was added before rather than after ${ }^{57} \mathrm{Fe}$ (II). The open orange squares in Figure $2 \mathrm{~B}, \mathrm{C}$ show that, at $\mathrm{pH} 7.0$ and $8.5,75-100 \%$ of the added ${ }^{57} \mathrm{Fe}$ tracer is measured as $\left[{ }^{57} \mathrm{Fe}\right]_{\text {tracer,diss. }}$ over the entire experimental period. Preequilibration of Lp with DFOB inhibits the adsorption of ${ }^{57} \mathrm{Fe}$ (II) and presumably also the isotopic exchange with surface $\mathrm{Fe}$ (III) that was observed in the absence of DFOB. A reasonable fit to the data at $\mathrm{pH} 6.0$ and 7.0 was achieved with the detailed, mechanistic kinetic model (lines in Figure 2A,B) as described below.

Kinetic Model. In our recent study, we presented a kinetic model for the dissolution of Lp with EDTA at $\mathrm{pH} 6.0$ that was able to describe the entire course of the dissolution. ${ }^{27}$ Here, we extended this model to the dissolution of Lp with DFOB and added reactions to describe the observed adsorption and release of ${ }^{57} \mathrm{Fe}$. We also tested possible explanations for the delayed release of ${ }^{57} \mathrm{Fe}$ when ${ }^{57} \mathrm{Fe}$ (II) was added before the ligand. In particular, the model allows us to estimate the charge delocalization between added ${ }^{57} \mathrm{Fe}$ (II) and ${ }^{56} \mathrm{Fe}(\mathrm{III})$ in $\mathrm{Lp}$ 


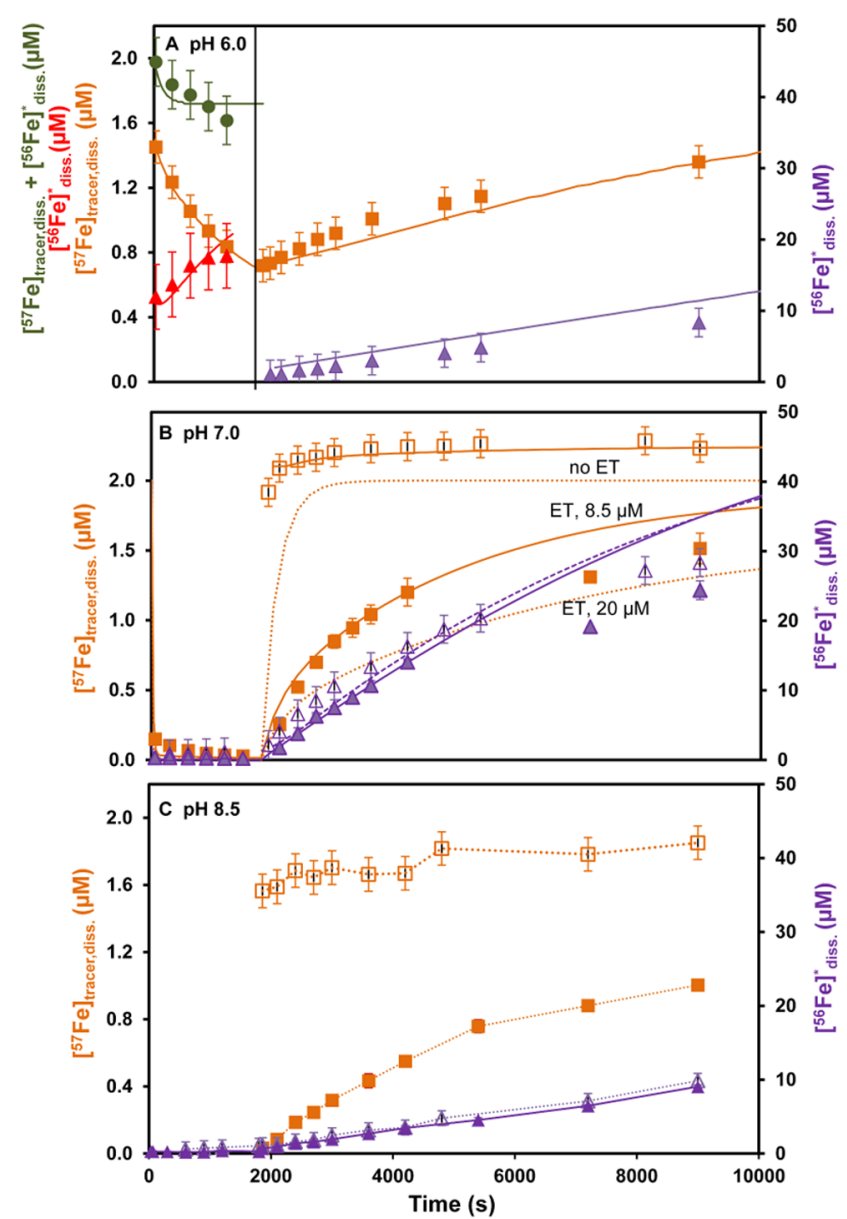

Figure 2. ${ }^{57} \mathrm{Fe}$ isotope exchange and $\mathrm{Lp}$ dissolution under anoxic conditions as a function of time at (A) $\mathrm{pH} 6.0$ (MES), (B) $\mathrm{pH} 7.0$ (carbonate buffer), and (C) $\mathrm{pH} 8.5$ (PIPES). ${ }^{57} \mathrm{Fe}(\mathrm{II})(2 \mu \mathrm{M})$ was added to an Lp suspension (1125 $\mu \mathrm{M}) 1800 \mathrm{~s}$ before (filled symbols, error bars correspond to the ranges of duplicate experiments) or after (empty symbols, error bars as in Figure 1) $50 \mu \mathrm{M}$ DFOB addition. Symbols: purple triangles (right axis): concentration of $\mathrm{Fe}$ released into solution by $\mathrm{Lp}$ dissolution $\left(\left[{ }^{56} \mathrm{Fe}\right] *\right.$ diss. $)$; orange squares (left axis): dissolved concentration of tracer ${ }^{57} \mathrm{Fe}$ corrected for the natural abundance of ${ }^{57} \mathrm{Fe}$ in $\mathrm{Lp}\left(\left[{ }^{57} \mathrm{Fe}\right]_{\text {tracer,diss. }}\right)$; red triangles (left axis): concentration of ${ }^{56} \mathrm{Fe}^{*}$ in solution resulting from isotopic exchange of ${ }^{57} \mathrm{Fe}$ with ${ }^{56} \mathrm{Fe}$ in $\mathrm{Lp}(t<1800 \mathrm{~s})$; green circles (left axis): sum of dissolved concentration of $\mathrm{Fe}$ measured as $\left[{ }^{57} \mathrm{Fe}\right]_{\text {tracer,diss. }}$ and $\left[{ }^{56} \mathrm{Fe}\right]{ }_{\text {diss. }}(t<1800 \mathrm{~s})$. Lines: $(\mathrm{A}, \mathrm{B})$ Kinetic model fits to the measured data. The solid orange lines show the fits with the optimized concentration of surface sites $(8.5 \mu \mathrm{M})$ for ET between $\equiv \mathrm{Fe}^{\mathrm{III}}-\mathrm{O}-{ }^{57} \mathrm{Fe}^{\mathrm{II}}$ and $\equiv{ }^{57} \mathrm{Fe}^{\mathrm{III}}-\mathrm{O}-\mathrm{Fe}^{\mathrm{II}}$ sites (R6 in the kinetic model). The dotted orange lines show release of ${ }^{57} \mathrm{Fe}$ that is too fast with no ET or too slow with ET between more surface sites $(20 \mu \mathrm{M})$. In (C), the lines are only shown as visual guides.

before and during the dissolution process. Table 2 lists important reaction steps in the kinetic model describing the dissolution of Lp with DFOB and the acceleration by added $\mathrm{Fe}(\mathrm{II})$.

When DFOB is added before ${ }^{57} \mathrm{Fe}$ (II), it adsorbs reversibly to the surface at $\mathrm{Fe}(\mathrm{III})$ sites (R1) and causes slow ligandcontrolled dissolution (R2). Upon addition of ${ }^{57} \mathrm{Fe}(\mathrm{II})$, dissolved ${ }^{57} \mathrm{Fe}$ (II)DFOB is formed quickly (R3). Adsorption of ${ }^{57} \mathrm{Fe}$ (II)DFOB, ET, and detachment of ${ }^{57} \mathrm{Fe}$ (III)DFOB are aggregated in reaction R4-1. We assume that upon adsorption, negative charge is transferred to $\mathrm{Lp}$, due to the strongly reducing properties of $\mathrm{Fe}(\mathrm{II})$ complexed to $\mathrm{DFOB}$, but we cannot resolve the individual reaction steps experimentally. R42 shows an alternative pathway leading to the same overall reaction. After detachment from the surface, ${ }^{57} \mathrm{Fe}$ (III)DFOB does not undergo further reactions. ${ }^{44-47}$ Reactions R4-1 and R4-2 are the dominant reaction pathways for the initial transfer of negative charge when ${ }^{57} \mathrm{Fe}$ (II) is added in the presence of DFOB. Adsorption of ${ }^{57} \mathrm{Fe}(\mathrm{II})$ is minimal in this case, and added ${ }^{57} \mathrm{Fe}$ thus remains in solution, as shown in Figure 2B.

When ${ }^{57} \mathrm{Fe}$ (II) is added first, it is reversibly adsorbed (R5) and charge transfer to $\mathrm{Fe}$ (III) can occur at the surface (R6). We cannot determine rate coefficients for charge transfer, only the distribution of charge on the surface. In the model, we assume charge transfer and equilibration of charge on a time scale of seconds to minutes for Lp and adjust the concentration of the surface sites over which the charge can distribute. In the absence of DFOB, the sequence of adsorption, charge transfer, and desorption (R5-R7) can explain the isotope exchange between ${ }^{57} \mathrm{Fe}$ (II) in solution and ${ }^{56} \mathrm{Fe}$ (II) on the surface (formed by ET from an adsorbed ${ }^{57} \mathrm{Fe}$ (II) to a surface $\left.{ }^{56} \mathrm{Fe}(\mathrm{III})\right)$. The exchange of dissolved ${ }^{57} \mathrm{Fe}(\mathrm{II})$ with ${ }^{56} \mathrm{Fe}(\mathrm{II})$ from the surface was observable in the filtered solutions at $\mathrm{pH}$ 6.0, but it was not measurable at $\mathrm{pH} 7.0$ because dissolved equilibrium concentrations were too low. Note that we assumed that charge transfer at the surface is fast $(>1 \times$ $10^{-1} \mathrm{~s}^{-1}$ ) and that equilibration of charge between ${ }^{56} \mathrm{Fe}$ and ${ }^{57} \mathrm{Fe}$ surface is reached within minutes or faster for $\mathrm{Lp}$, while adsorption and desorption reactions are slower. Soltis et al. ${ }^{48}$ reported that lifetimes of electrons in deep traps on the surface of ferrihydrite cover a large range and can reach microseconds or longer. In our model, rate coefficients for ET from $1 \times 10^{-1}$ to $1 \times 10^{6} \mathrm{~s}^{-1}$ (which yield good fits with $\mathrm{Lp}$ ) are thus in the expected range. Charge transfer and distribution of charge is slower for Gt, as discussed below.

Ligand that is added after $\mathrm{Fe}(\mathrm{II})$ or is present in excess over added $\mathrm{Fe}$ (II) (which was always the case in our experiments) can react with surface-bound $\mathrm{Fe}(\mathrm{II})$. Ligand adsorption to surface-bound $\mathrm{Fe}(\mathrm{II})$, charge transfer, and detachment are summarized in reactions R8 and R9. We assumed that charge transfer from a $\mathrm{Fe}(\mathrm{II})$ surface site with adsorbed DFOB to a neighboring $\mathrm{Fe}$ (III) site is rapid (due to strongly reducing properties of $\mathrm{Fe}$ (II) complexed to DFOB). Once formed, the adsorbed $\mathrm{Fe}(\mathrm{III}) \mathrm{L}$ detaches more quickly than in reaction $\mathrm{R} 2$, due to weaker $\mathrm{Fe}(\mathrm{II})-\mathrm{O}-\mathrm{Fe}$ (III) bonds to the neighboring $\mathrm{Fe}(\mathrm{II})$, compared to $\mathrm{Fe}(\mathrm{III})-\mathrm{O}-\mathrm{Fe}(\mathrm{III})$ bonds. The larger rate coefficients associated with reactions $\mathrm{R} 8$ and $\mathrm{R} 9$ compared to dissolution in the absence of $\mathrm{Fe}(\mathrm{II})$ (R2) account for the $\mathrm{Fe}(\mathrm{II})$-catalyzed accelerated dissolution. Reactions R6 and R8$\mathrm{R} 9$ explain the release of ${ }^{57} \mathrm{Fe}(\mathrm{III}) \mathrm{L}$ and $\mathrm{Fe}(\mathrm{III}) \mathrm{L}$ and their ratios over the course of the dissolution. Finally, reactions R10 and R11 describe the rapid formation of new surface sites.

As explained in Table 2, some equilibrium constants and rate coefficients were fixed (italic font) and others optimized (normal font). Modeling was performed to determine whether the suggested reaction steps could fit the measured data. Values for the rate coefficients and equilibrium constants could not be uniquely determined because of correlations among them. For example, the values for the adsorption equilibrium constants in R1, R5, and R7 cannot be determined independently from the values of the rate coefficients for dissolution in R4, R8, and R9. However, equilibrium constants obtained in previous work ${ }^{28}$ can be used to constrain fitted values of rate coefficients. The model is very sensitive to the 
Table 2. Kinetic Model with List of Reactions and Equilibrium Constants $(K)$ and Rate Coefficients $(k)$

\begin{tabular}{|c|c|c|c|c|}
\hline nr. & reaction $^{a}$ & description & $K / k^{b} \mathrm{pH} 7$ & $K / k^{b} \mathrm{pH} 6$ \\
\hline $\mathrm{R} 1$ & $\equiv \mathrm{Fe}^{\mathrm{III}}+\mathrm{L} \rightleftarrows \equiv \mathrm{Fe}^{\mathrm{III}} \mathrm{L}$ & adsorption of ligand $(\mathrm{L})$ on surface $\mathrm{Fe}^{\mathrm{III}}$ & $3.0 \times 10^{5 c}$ & $3 \times 10^{4}$ to $3 \times 10^{5 c}$ \\
\hline $\mathrm{R} 2$ & $\equiv \mathrm{Fe}^{\mathrm{III}} \mathrm{L} \rightarrow \equiv \mathrm{Fe}^{\mathrm{III}}+\mathrm{Fe}^{\mathrm{III}} \mathrm{L}$ & noncatalyzed dissolution & $3.5 \times 10^{-5}$ & n.d. ${ }^{d}$ \\
\hline $\mathrm{R} 3$ & ${ }^{57} \mathrm{Fe}^{\mathrm{II}}+\mathrm{L} \rightleftarrows{ }^{57} \mathrm{Fe}^{\mathrm{II}} \mathrm{L}$ & dissolved ${ }^{57} \mathrm{Fe}^{\mathrm{II}} \mathrm{L}$ complex formation & $5.3 \times 10^{4 e}$ & $3.8 \times 10^{2 e}$ \\
\hline R4-1 & $\equiv \mathrm{Fe}^{\mathrm{III}}+{ }^{57} \mathrm{Fe}^{\mathrm{II}} \mathrm{L} \rightarrow \equiv \mathrm{Fe}^{\mathrm{II}}+{ }^{57} \mathrm{Fe}^{\mathrm{III}} \mathrm{L}$ & ET from ${ }^{57} \mathrm{Fe}^{\mathrm{II}} \mathrm{L}$ to surface $\mathrm{Fe}{ }^{\mathrm{III}}$ and detachment of ${ }^{57} \mathrm{Fe}^{\mathrm{III}} \mathrm{L}$ & $1.4 \times 10^{2}$ & $200-600$ \\
\hline $\mathrm{R} 4-2$ & $\equiv \mathrm{Fe}^{\mathrm{III}} \mathrm{L}+{ }^{57} \mathrm{Fe}^{\mathrm{II}} \rightarrow \equiv \mathrm{Fe}^{\mathrm{II}}+{ }^{57} \mathrm{Fe}^{\mathrm{III}} \mathrm{L}$ & ET from ${ }^{57} \mathrm{Fe}^{\mathrm{II}}$ to surface $\mathrm{Fe}^{\mathrm{III}} \mathrm{L}$ and detachment of ${ }^{57} \mathrm{Fe}^{\mathrm{III}} \mathrm{L}$ & $2.2 \times 10^{4}$ & \\
\hline R5 & $\equiv \mathrm{Fe}^{\mathrm{III}}+{ }^{57} \mathrm{Fe}^{\mathrm{II}} \rightleftarrows \equiv \mathrm{Fe}^{\mathrm{III}}-\mathrm{O}-{ }^{57} \mathrm{Fe}^{\mathrm{II}}$ & adsorption and desorption of ${ }^{57} \mathrm{Fe}^{\mathrm{II}}$ on surface $\mathrm{Fe}{ }^{\mathrm{III}}$ & $7.2 \times 10^{6}$ & $6.3 \times 10^{4}$ \\
\hline R6 & $\equiv \mathrm{Fe}^{\mathrm{III}}-\mathrm{O}-{ }^{57} \mathrm{Fe}^{\mathrm{II}} \rightleftarrows \equiv{ }^{57} \mathrm{Fe}^{\mathrm{III}}-\mathrm{O}-\mathrm{Fe}^{\mathrm{II}}$ & ET between ${ }^{57} \mathrm{Fe}$ and ${ }^{56} \mathrm{Fe}$ surface sites $\left(K_{\mathrm{ex}}\right)$ & $k_{\mathrm{ET}}>0.1 \mathrm{~K}=1^{f}$ & $k_{\mathrm{ET}}>0.1 \mathrm{~K}=1^{f}$ \\
\hline R7 & $\equiv{ }^{57} \mathrm{Fe}^{\mathrm{III}}+\mathrm{Fe}^{\mathrm{II}} \rightleftarrows \equiv{ }^{57} \mathrm{Fe}^{\mathrm{III}}-\mathrm{O}-\mathrm{Fe}^{\mathrm{II}}$ & adsorption and desorption of $\mathrm{Fe}^{\mathrm{II}}$ on surface ${ }^{57} \mathrm{Fe}^{\mathrm{III}}$ & $7.2 \times 10^{6}$ & $6.3 \times 10^{4}$ \\
\hline R8 & $\equiv \mathrm{Fe}^{\mathrm{III}}-\mathrm{O}-{ }^{57} \mathrm{Fe}^{\mathrm{II}}+\mathrm{L} \rightarrow \equiv \mathrm{Fe}^{\mathrm{II}}+{ }^{57} \mathrm{Fe}^{\mathrm{III}} \mathrm{L}$ & adsorption of $\mathrm{L}$ on adsorbed ${ }^{57} \mathrm{Fe}^{\mathrm{II}}, \mathrm{ET}$, and detachment & 61 & $<5$ \\
\hline R9 & $\equiv{ }^{57} \mathrm{Fe}^{\mathrm{III}}-\mathrm{O}-\mathrm{Fe}^{\mathrm{II}}+\mathrm{L} \rightarrow \equiv{ }^{57} \mathrm{Fe}^{\mathrm{II}}+\mathrm{Fe}^{\mathrm{III}} \mathrm{L}$ & adsorption of $\mathrm{L}$ on adsorbed $\mathrm{Fe}^{\mathrm{II}}, \mathrm{ET}$, and detachment & 61 & $<5$ \\
\hline $\mathrm{R} 10^{g}$ & $\equiv \mathrm{Fe}^{\mathrm{II}}+$ bulk $\rightarrow \equiv \mathrm{Fe}^{\mathrm{III}}-\mathrm{O}-\mathrm{Fe}^{\mathrm{II}}$ & re-formation of surface site with adsorbed $\mathrm{Fe}^{\mathrm{II}}$ & $1 \times 10^{10}$ & $1 \times 10^{10}$ \\
\hline $\mathrm{R} 11^{g}$ & $\equiv{ }^{57} \mathrm{Fe}^{\mathrm{II}}+$ bulk $\rightarrow \equiv \mathrm{Fe}^{\mathrm{III}}-\mathrm{O}-{ }^{57} \mathrm{Fe}^{\mathrm{II}}$ & re-formation of surface site with adsorbed ${ }^{57} \mathrm{Fe}^{\mathrm{II}}$ & $1 \times 10^{10}$ & $1 \times 10^{10}$ \\
\hline \multirow[t]{2}{*}{$\mathrm{R} 12^{h}$} & $\begin{array}{l}\equiv \mathrm{Fe}^{\mathrm{III}}-\mathrm{O}-{ }^{57} \mathrm{Fe}^{\mathrm{II}}+\text { phen } \rightarrow \\
\equiv \mathrm{Fe}^{\mathrm{III}}+{ }^{57} \mathrm{Fe}^{\mathrm{II}} \text { phen }\end{array}$ & $\begin{array}{l}\text { desorption of }{ }^{57} \mathrm{Fe} \text { with phen (adjusted to desorption of } 51 \% \\
\mathrm{Fe}(\mathrm{II}) \text { ) }\end{array}$ & $20(\mathrm{Gt}) 120(\mathrm{Lp})$ & \\
\hline & & initial concentration of active surface sites $\left(\left[\equiv \mathrm{Fe}^{\mathrm{III}}\right]_{0}\right)$ & $8.5 \mu \mathrm{M}$ & $8.5 \mu \mathrm{M}$ \\
\hline
\end{tabular}

${ }^{a}$ In the surface complexation reactions, the type of surface complex (e.g., monodentate and/or bidentate) is not specified. Surface hydroxyl groups are thus omitted and reactions are not balanced for $\mathrm{OH}^{-}, \mathrm{H}^{+}$, and $\mathrm{H}_{2} \mathrm{O}$. For example, in $\mathrm{R} 1, \equiv \mathrm{Fe} \mathrm{eII}^{\mathrm{II}} \mathrm{L} \rightarrow \equiv \mathrm{Fe}^{\mathrm{III}} \mathrm{L}$ represents the sum of surface complexation reactions, such as $\equiv \mathrm{Fe}^{\mathrm{III}} \mathrm{OH}+\mathrm{HL} \rightarrow \equiv \mathrm{Fe}^{\mathrm{III}} \mathrm{L}+\mathrm{H}_{2} \mathrm{O}$ and $\equiv \mathrm{Fe}^{\mathrm{III}}(\mathrm{OH})_{2}+\mathrm{H}_{2} \mathrm{~L} \rightarrow \equiv \mathrm{Fe}^{\mathrm{III}} \mathrm{L}+2 \mathrm{H}_{2} \mathrm{O}$. Bonds between Fe ions consisting of several $(\mu$-oxo) and ( $\mu$-hydroxo) bonds are represented in simplified form as $\mathrm{Fe}-\mathrm{O}-\mathrm{Fe}$. The optimized initial concentration of surface sites $\left(\left[\equiv \mathrm{Fe}^{\mathrm{III}}\right]\right)$ in the model was $8.5 \mu \mathrm{M} .{ }^{56} \mathrm{Fe}$ is abbreviated as Fe. All reactions with Fe and ${ }^{57} \mathrm{Fe}$ isotopes in solution and on the surface include the additional of the four possible permutations. For example, in $\mathrm{R} 4-1: \equiv \mathrm{Fe}^{\mathrm{III}}+{ }^{57} \mathrm{Fe}^{\mathrm{II}} \mathrm{L} \rightarrow \equiv \mathrm{Fe}^{\mathrm{II}}+{ }^{57} \mathrm{Fe}^{\mathrm{III}} \mathrm{L}$ also $\mathrm{R} 4-1 \mathrm{~b}: \equiv \mathrm{Fe}^{\mathrm{III}}+\mathrm{Fe}^{\mathrm{II}} \mathrm{L} \rightarrow$ $\equiv \mathrm{Fe}^{\mathrm{II}}+\mathrm{Fe}^{\mathrm{III}} \mathrm{L}, \mathrm{R} 4-1 \mathrm{c}: \equiv{ }^{57} \mathrm{Fe}^{\mathrm{III}}+\mathrm{Fe}^{\mathrm{II}} \mathrm{L} \rightarrow \equiv{ }^{57} \mathrm{Fe}^{\mathrm{II}}+\mathrm{Fe}^{\mathrm{III}} \mathrm{L}$, and $\mathrm{R} 4-1 \mathrm{~d}: \equiv{ }^{57} \mathrm{Fe}^{\mathrm{III}}+{ }^{57} \mathrm{Fe}^{\mathrm{II}} \mathrm{L} \rightarrow \equiv{ }^{57} \mathrm{Fe}^{\mathrm{II}}+{ }^{57} \mathrm{Fe}^{\mathrm{III}} \mathrm{L}$. The full list of reactions is provided in Table S3. ${ }^{b} \mathrm{~K}$ and $k$ are fitted equilibrium constants and rate coefficients $\left(\mathrm{M}^{-1}, \mathrm{~s}^{-1}\right.$, and $\left.\mathrm{M}^{-1} \mathrm{~s}^{-1}\right)$. Numbers in normal font are fitted values; numbers in italic font are values from previous work, from the literature, or are non-rate-determining rate coefficients. ${ }^{c}$ Values from Borer et al. 2009. ${ }^{47}$ Fitted value for $\mathrm{pH} 7.0$, not determined for $\mathrm{pH} 6.0$ (not critical for model fits at $\mathrm{pH} 6.0$ ). ${ }^{e}$ Calculated with DFOB complex formation constants reported by Kim et al., $2010 .{ }^{49}$ See Figure S8 in the SI for more information. ${ }^{f}$ Rate coefficients $\left(k_{\mathrm{ET}}\right)$ for exchange of charge between ${ }^{57} \mathrm{Fe}$ and ${ }^{56} \mathrm{Fe}$ surface sites. Note that $\equiv{ }^{57} \mathrm{Fe}^{\mathrm{III}}-\mathrm{O}-\mathrm{Fe}^{\mathrm{II}}$ and $\equiv \mathrm{Fe}^{\mathrm{III}}-\mathrm{O}-{ }^{57} \mathrm{Fe}^{\mathrm{II}}$ do not have to be neighboring sites, only rapid charge transfer between the sites has to be possible. ${ }^{g}$ In the model, bulk-Lp contains only ${ }^{56} \mathrm{Fe}$ (again, abbreviated as Fe) (reactions R10 and R11). This is consistent with the experimental results, in which the measured ${ }^{56} \mathrm{Fe}$ concentrations are scaled to represent the concentrations of the sum of Fe isotopes in Lp. ${ }^{h}$ Desorption of $\mathrm{Fe}(\mathrm{II})$ with phen and formation of $\mathrm{Fe}(\mathrm{II})(\mathrm{phen}){ }_{3}{ }^{2+}$ is abbreviated in this reaction. It is assumed that the first step (formation of $\mathrm{Fe}(\mathrm{II})$ phen $\left.^{2+}\right)$ is rate-determining and complexation with two more phen is rapid. Phen is in large excess $(100 \mu \mathrm{M})$ and the change in the concentration of uncomplexed phen does not affect the desorption kinetics.

value of the surface site concentration over which exchange of charge can take place in the time before and during dissolution in reaction $\mathrm{R} 6$. Without exchange of charge $\left(k_{\mathrm{ET}}<1 \times 10^{-6}\right.$ $\left.\mathrm{s}^{-1}\right)$, the model predicts a very quick release of ${ }^{57} \mathrm{Fe}$ after addition of the ligand (dotted orange line in Figure $2 \mathrm{~B}$ ), in disagreement with the data. With values of $k_{\mathrm{ET}}$ from $1 \times 10^{-1}$ to $10^{6} \mathrm{~s}^{-1}$ and a distribution of the negative charge of $2 \mu \mathrm{M}$ adsorbed $\mathrm{Fe}(\mathrm{II})$ over $8-9 \mu \mathrm{M}$ surface sites (each charge in average distributed over $4.0-4.5$ sites), we obtain good fits (solid orange line, fit with $8.5 \mu \mathrm{M}$ surface sites). A distribution of charge over more sites (e.g., $20 \mu \mathrm{M}$ ) leads to a slower release of ${ }^{57} \mathrm{Fe}$ than experimentally observed (dotted orange line). Additional plots with model outputs for charge transfer occurring only before addition of DFOB are shown in Figure S9. The best fits were obtained with ET occurring before and during dissolution.

The validity for distribution of each negative charge over an average of 4.0-4.5 sites is also illustrated by the plot of $\left[{ }^{57} \mathrm{Fe}\right]_{\text {tracer,diss. }}$ as a function of $\left[{ }^{56} \mathrm{Fe}\right]{ }^{*}$ diss. (Figure 3 ). The data for $\mathrm{pH} 7.0$ and 8.5 (for both 20 and $50 \mu \mathrm{M}$ DFOB and for both carbonate and MOPS buffers) collapse onto a single curve. The offset of the data for $\mathrm{pH} 6.0$ corresponds to the presence of dissolved $\mathrm{Fe}(\mathrm{II})$ at the time of DFOB addition. At the start of the dissolution, the ratio of ${ }^{57} \mathrm{Fe} /{ }^{56} \mathrm{Fe}$ (i.e., the slope of the line for $\mathrm{pH} \mathrm{7.0)}$ is 0.23 , which means that the release of ${ }^{56} \mathrm{Fe}$ is about 4 -fold larger than that of ${ }^{57} \mathrm{Fe}$, independent of DFOB concentrations. During dissolution, the ratio of ${ }^{57} \mathrm{Fe} /{ }^{56} \mathrm{Fe}$ in solution continually decreases because less and less ${ }^{57} \mathrm{Fe}$ is present at the surface, as new surface sites are

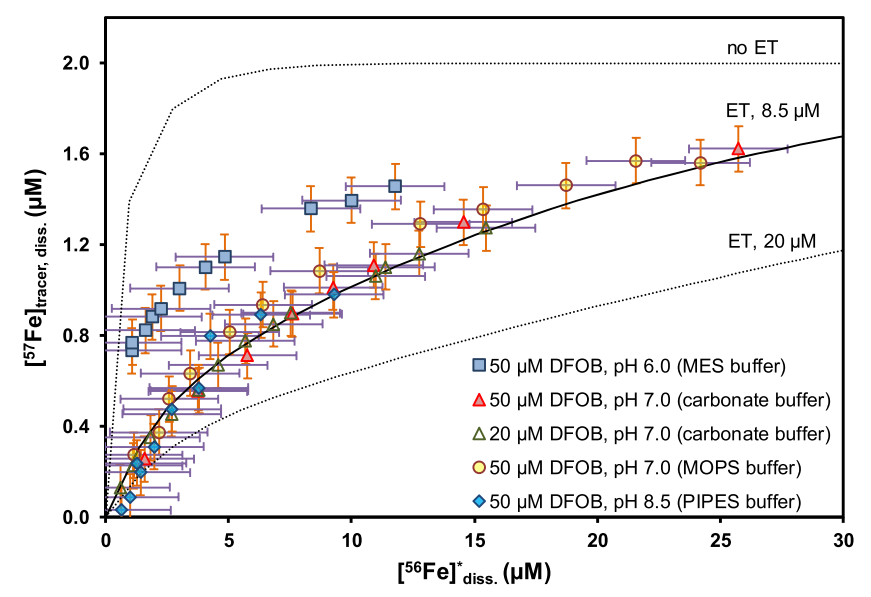

Figure 3. Release of tracer ${ }^{57} \mathrm{Fe}$ in solution as a function of dissolved ${ }^{56} \mathrm{Fe} *$ (Fe released from Lp) during accelerated Lp dissolution $(t>$ $1800 \mathrm{~s}$ ) when $2 \mu \mathrm{M}{ }^{57} \mathrm{Fe}$ (II) was added $1800 \mathrm{~s}$ before DFOB (same data used for $50 \mu \mathrm{M}$ DFOB treatment at $\mathrm{pH} 6.0, \mathrm{pH} 7.0$ (carbonatebuffered), and $\mathrm{pH} 8.5$, as shown in Figure 2). The solid and dotted lines represent the kinetic model fits to the data. The solid line shows the fit to the ${ }^{57} \mathrm{Fe}$ data at $\mathrm{pH} 7.0$ with the optimized concentration of surface sites $(8.5 \mu \mathrm{M})$ for ET between $\equiv \mathrm{Fe}^{\mathrm{III}}-\mathrm{O}-{ }^{57} \mathrm{Fe}^{\mathrm{II}}$ and $\equiv{ }^{57} \mathrm{Fe}^{\mathrm{III}}-\mathrm{O}-\mathrm{Fe}^{\mathrm{II}}$ sites. (R6 in the kinetic model). The dotted lines show release of ${ }^{57} \mathrm{Fe}$ that is too fast with no ET, or too slow with ET over more surface sites $(20 \mu \mathrm{M})$. Data for $50 \mu \mathrm{M}$ DFOB buffered with MOPS and $20 \mu \mathrm{M}$ DFOB buffered with carbonate are shown in SI Figure S6. 
formed from bulk ${ }^{56} \mathrm{Fe}$ (R11). The plots in Figure 3 suggest that adsorption of $\mathrm{Fe}$ (II) to Lp leads to exchange of charge on the surface before and during dissolution, largely independent of ligand concentrations. As the model fits (solid lines in Figure 2A,B) show, the model is able to explain our observed dissolution rates in the absence and presence of $\mathrm{Fe}(\mathrm{II})$ and the isotope exchange and release of ${ }^{57} \mathrm{Fe}$ and ${ }^{56} \mathrm{Fe}$ during dissolution.

The values for the rate coefficient for accelerated dissolution in reactions $\mathrm{R} 8$ and $\mathrm{R} 9$ (after adsorption of $\mathrm{Fe}$ (II) and transfer of negative charge from dissolved Fe(II)DFOB to the surface) of $61 \mathrm{M}^{-1} \mathrm{~s}^{-1}$ are in the range, but somewhat lower than the value for $k_{\mathrm{C} \text {,app }}$ of $93 \mathrm{M}^{-1} \mathrm{~s}^{-1}$ obtained in our empirical model, because reactions R4-1 and R4-2 in the more complex model also contribute to the dissolution. The empirical model does overpredict the rate of dissolution at later time points (e.g., results for $1 \mu \mathrm{M} \mathrm{Fe}$ (II) and $50 \mu \mathrm{M}$ DFOB in Figure 1B). Kim et al. $^{49}$ reported oxidation of $\mathrm{Fe}(\mathrm{II})$ in autodecomposition reactions of $\mathrm{Fe}$ (II)DFOB, but this reaction is too slow to affect $\mathrm{Fe}$ (II)-catalyzed dissolution on the time scale of our experiments and inclusion of oxidation reactions did not lead to significantly improved overall fits. Thus, we attribute the apparent decrease in the dissolution rate at longer times to slow oxidation of $\mathrm{Fe}$ (II) by low residual $\mathrm{O}_{2}$ concentrations.

${ }^{57} \mathrm{Fe}$ Isotope Exchange and Gt Dissolution. Several previous studies ${ }^{33,37,50}$ reported ${ }^{57} \mathrm{Fe}$ (II) isotope exchange with Gt in the absence of ligand over time scales of days to months, leading to ET and isotope exchange between aqueous ${ }^{57} \mathrm{Fe}$ (II) and solid ${ }^{56} \mathrm{Fe}$. Here, we examine isotope exchange only on shorter time scales of minutes to hours, before and during Gt dissolution.

When ${ }^{57} \mathrm{Fe}(\mathrm{II})$ was added before DFOB, $\left[{ }^{57} \mathrm{Fe}\right]_{\text {tracer,diss }}$ (solid orange squares) decreased over time at $\mathrm{pH} 7.0$ as shown in Figure 4. Since adsorption was almost complete within $1800 \mathrm{~s}$, formed $\left[{ }^{56} \mathrm{Fe}\right]^{*}{ }_{\text {diss. }}$ was too low for accurate determination before addition of DFOB.

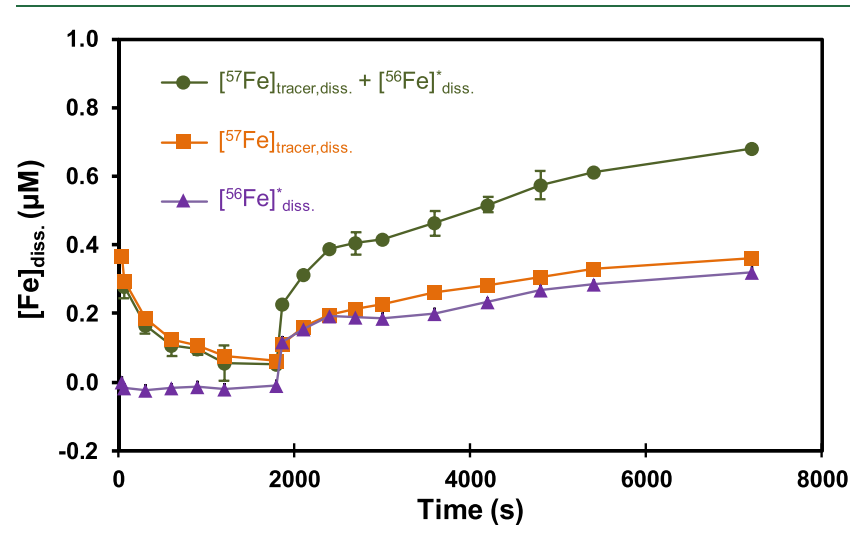

Figure 4. ${ }^{57} \mathrm{Fe}$ isotope exchange and goethite dissolution at $\mathrm{pH} 7.0$ (carbonate-buffered) under anoxic conditions. ${ }^{57} \mathrm{Fe}(\mathrm{II})(2 \mu \mathrm{M})$ was added to a goethite suspension $(1125 \mu \mathrm{M}) 1800 \mathrm{~s}$ before $50 \mu \mathrm{M}$ $\mathrm{DFOB}$ addition. The error bars correspond to the range of duplicate measurements. Data points under negative values represent measurements which were below the detection limit. The lines serve as visual guides. Symbols: purple triangles: concentration of Fe released into solution by goethite dissolution $\left(\left[{ }^{56} \mathrm{Fe}\right]{ }^{*}\right.$ diss. $)$; orange squares: dissolved concentration of tracer ${ }^{57} \mathrm{Fe}$ corrected for the natural abundance of ${ }^{57} \mathrm{Fe}$ in goethite $\left(\left[{ }^{57} \mathrm{Fe}\right]_{\text {tracer,diss }}\right)$; green circles: sum of dissolved concentration of $\mathrm{Fe}$ measured as $\left[{ }^{57} \mathrm{Fe}\right]_{\text {tracer,diss. }}$ and $\left[{ }^{56} \mathrm{Fe}\right]{ }^{*}$ diss. representing the total dissolved $\mathrm{Fe}$ concentration.
Addition of $50 \mu \mathrm{M}$ DFOB led to accelerated dissolution, shown by increasing $\left[{ }^{56} \mathrm{Fe}\right]{ }^{*}$ diss. (filled purple triangles) and total dissolved Fe (green filled circles). Notably, $\left[{ }^{57} \mathrm{Fe}\right]_{\text {tracer,diss. }}$ increased at a similar rate to $\left[{ }^{56} \mathrm{Fe}\right]{ }^{*}{ }_{\text {diss }}$ in contrast to $\mathrm{Lp}$ where $\left[{ }^{56} \mathrm{Fe}\right]{ }_{\text {diss }}$ increased by a factor of around 4 faster than $\left[{ }^{57} \mathrm{Fe}\right]_{\text {tracer,diss. }}$ This indicates that within our experimental time scale, the extent of isotope exchange was much smaller for Gt than for Lp. As also reported in our previous work, ${ }^{28}$ dissolution of $\mathrm{Gt}$ is slower than that of $\mathrm{Lp}$ at $\mathrm{pH}$ 7.0, at a rate which is in good agreement with our previously reported rate (Figure S7). We did not attempt to apply our kinetic model to dissolution of Gt because the dissolution was slow and the concentration of dissolved $\mathrm{Fe}$ remained below the added $\mathrm{Fe}(\mathrm{II})$ concentration. The measured concentrations could thus be the result of desorption and Fe from dissolution of $\mathrm{Gt}$, but the concentrations are too low to separate the two processes. Experiments over longer time scales were not attempted due to slow oxidation of $\mathrm{Fe}$ (II) by residual oxygen, which could not be completely prevented in experiments requiring an anoxic atmosphere with $2 \% \mathrm{CO}_{2}$.

${ }^{57} \mathrm{Fe}$ Isotope Exchange without Net Dissolution. Phen was added after adsorption of ${ }^{57} \mathrm{Fe}$ (II) to desorb $\mathrm{Fe}$ (II) and to allow analysis of its isotopic composition. Control experiments were performed with phen added before ${ }^{57} \mathrm{Fe}$ (II).

Lp. As shown in Figure 5A, $2 \mu \mathrm{M}{ }^{57} \mathrm{Fe}$ (II) added before phen was almost completely adsorbed within $1800 \mathrm{~s}$ at $\mathrm{pH} 7$, consistent with the data shown in Figure 2B. Upon addition of $100 \mu \mathrm{M}$ phen, $1.0 \mu \mathrm{M}$ total $\mathrm{Fe}$ (II) was desorbed, of which $\sim 20 \%$ was ${ }^{57} \mathrm{Fe}$ (II) and $\sim 80 \%$ was ${ }^{56} \mathrm{Fe}(\mathrm{II})$. Although only $51 \%$ of the added $\mathrm{Fe}(\mathrm{II})$ was desorbed, the ratio of $\left[{ }^{56} \mathrm{Fe}(\mathrm{II})\right] *{ }_{\text {diss. }} /\left[{ }^{57} \mathrm{Fe}\right]_{\text {tracer,diss. }}$ of $\sim 4$ indicates that extensive charge transfer occurred and the ratio is comparable to the ratio of 4.0-4.5 at the start of accelerated Lp dissolution with DFOB. The solid lines show model fits with ET between $\equiv \mathrm{Fe}^{\mathrm{III}}-\mathrm{O}-{ }^{57} \mathrm{Fe}^{\mathrm{II}}$ and $\equiv{ }^{57} \mathrm{Fe}^{\mathrm{III}}-\mathrm{O}-\mathrm{Fe}^{\mathrm{II}}$ over the optimized concentration of surface sites $(8.5 \mu \mathrm{M})$. The model correctly reproduces the relative concentrations of desorbed ${ }^{57} \mathrm{Fe}$ and ${ }^{56} \mathrm{Fe}$. (To account for the incomplete desorption of adsorbed $\mathrm{Fe}$ (II) by phen, model output concentrations were multiplied by 0.51 for Lp.) Incomplete desorption can be due to ET to surface sites where $\mathrm{Fe}(\mathrm{II})$ is strongly bound and is not desorbed by addition of phen. In a control experiment with ${ }^{57} \mathrm{Fe}$ (II) added after phen, all added ${ }^{57} \mathrm{Fe}$ (open circles) remained in solution.

Gt. Very different results were obtained with Gt, as shown in Figure 5B. ${ }^{57} \mathrm{Fe}(\mathrm{II})$ added before phen was again almost completely adsorbed, with no detectable release of ${ }^{56} \mathrm{Fe}$. Addition of phen leads to release of adsorbed Fe(II), although more slowly than with $\mathrm{Lp}$. In contrast to $\mathrm{Lp}$, more ${ }^{57} \mathrm{Fe}$ (II) than ${ }^{56} \mathrm{Fe}$ was released. From 4000 to $9000 \mathrm{~s}, 0.85 \mu \mathrm{M}$ total $\mathrm{Fe}$ (II) was desorbed, of which $76 \%$ was ${ }^{57} \mathrm{Fe}$ (II) and $24 \%$ was ${ }^{56} \mathrm{Fe}(\mathrm{II})$. The ratio of $\left[{ }^{56} \mathrm{Fe}(\mathrm{II})\right]^{*}{ }_{\text {diss. }} /\left[{ }^{57} \mathrm{Fe}\right]_{\text {tracer,diss. }}$ was 0.31 , in contrast to the ratio in $\mathrm{Lp}$ of $4.0-4.5$. These contrasting results show that much less charge transfer from added ${ }^{57} \mathrm{Fe}$ to ${ }^{56} \mathrm{Fe}$ in the solid must have occurred with Gt than with Lp. As shown by the solid lines (model output multiplied by 0.40 to account for incomplete desorption), the model can reproduce the data for Gt if we assume lower rate coefficients for ET in Gt (e.g., $k_{\mathrm{ET}}=1.2 \times 10^{-4} \mathrm{~s}^{-1}$ in the fit shown) than in Lp. Slow ET would allow only limited charge equilibration in the $1800 \mathrm{~s}$ before addition of phen. This contrasts with ET in Lp, where 

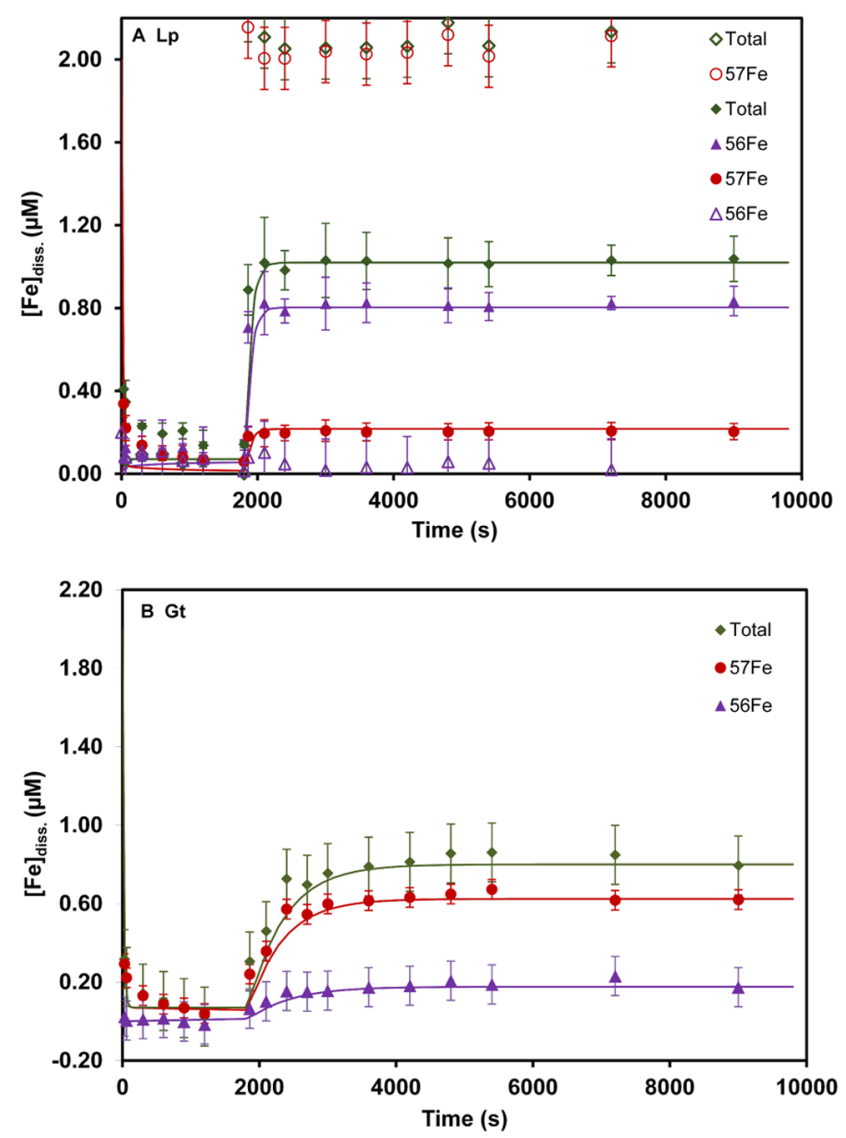

Figure 5. Adsorption and desorption of ${ }^{57} \mathrm{Fe}(\mathrm{II})$ (tracer) and ${ }^{56} \mathrm{Fe}(\mathrm{II})$ on (A) Lp and (B) Gt at pH 7.0 (carbonate-buffered) under anoxic conditions. ${ }^{57} \mathrm{Fe}(\mathrm{II})(2 \mu \mathrm{M})$ was added to the suspensions $(1125 \mu \mathrm{M})$ $1800 \mathrm{~s}$ before (filled symbols) or after (empty symbols) $100 \mu \mathrm{M}$ phenanthroline (phen) addition. Data points with negative values represent measurements below the detection limit. The error bars correspond to the range of duplicate measurements. The lines show model fits with ET between $8.5 \mu \mathrm{M}$ surface sites. Modeled concentrations were multiplied by 0.51 for Lp and by 0.40 for Gt to account for the incomplete desorption of adsorbed Fe(II) by phen. With Lp, mostly ${ }^{56} \mathrm{Fe}$ was released back into solution after addition of phen. In contrast, mostly ${ }^{57} \mathrm{Fe}$ was released back into solution with Gt. This can be rationalized with rate coefficients $\left(>1 \times 10^{-1} \mathrm{~s}^{-1}\right)$ for ET leading to rapid equilibration of charge among surface sites in Lp and slower ET and incomplete equilibration after $1800 \mathrm{~s}$ in Gt (the fits shown in (B) were obtained with $k_{\mathrm{ET}}=1.2 \times 10^{-4} \mathrm{~s}^{-1}$ ).

$k_{\mathrm{ET}}>1 \times 10^{-1} \mathrm{~s}^{-1}$ leads to full equilibration of charge between ${ }^{57} \mathrm{Fe}$ and ${ }^{56} \mathrm{Fe}$ over $8.5 \mu \mathrm{M}$ surface sites.

The rate for charge equilibration and isotope exchange on the surface of Lp and Gt is dependent not only on the rate of $\mathrm{ET}$ in reaction of R6 but also on the rates of adsorption and desorption of $\mathrm{Fe}(\mathrm{II})$ in reactions $\mathrm{R} 5$ and R7. To fit the over $90 \%$ adsorption of $\mathrm{Fe}$ (II) within $1-5 \mathrm{~min}$, we used rate coefficients in the range of $1 \times 10^{3}$ to $1 \times 10^{4} \mathrm{M}^{-1} \mathrm{~s}^{-1}$ (times for adsorption of $63 \%$ of the added $\mathrm{Fe}(\mathrm{II})$ of $12-120 \mathrm{~s}$ with $8.5 \mu \mathrm{M}$ surface sites) and of $1 \times 10^{-2}$ to $1 \times 10^{-3} \mathrm{~s}^{-1}$ (times for desorption of $63 \%$ of adsorbed $\mathrm{Fe}$ (II) of $100-1000 \mathrm{~s}$ ). We would like to point out that our model is a single-site surface model and thus rests on the assumption that one type of surface site can capture the average properties of many different surface sites with a range of properties regarding adsorption/desorption rates and equilibria and rates of ET between sites. The complexities of atom exchange on the surface and in the bulk of goethite as probed by atom tomography are presented and discussed in two recent articles. ${ }^{51,52}$ These studies show that atom exchange is spatially heterogeneous and occurs in exchange fronts that can penetrate several nanometers deep into the lattice, and is partly consistent with defect-accelerated exchange. Although our simple model can thus not be expected to capture all features of the experimental results, it explains our overall observations well and supports the proposed mechanisms.

Possible Mechanism for Lp Dissolution and Pathways for ${ }^{57} \mathrm{Fe}$ Isotope Exchange. DFOB Added First. In the presence of the ligand, interaction of dissolved ${ }^{57} \mathrm{Fe}$ (II)DFOB with the surface leads fast transfer of charge to surface $\mathrm{Fe}$ (III) and formation of dissolved ${ }^{57} \mathrm{Fe}$ (III)DFOB. This proposed mechanism is supported by the observation that virtually all of the ${ }^{57} \mathrm{Fe}$ added after DFOB remains in solution. Excess dissolved ligand can then complex surface-bound $\mathrm{Fe}(\mathrm{II})$, causing fast $\mathrm{ET}$ to a neighboring $\mathrm{Fe}$ (III) and subsequent detachment of Fe(III)DFOB. The ET and detachment steps can repeat until all of the free DFOB is consumed.

${ }^{57} \mathrm{Fe}(\mathrm{II})$ Added First. Charge can be transferred along the surface layer and possibly also into the bulk solid. Addition of DFOB again leads to complexation of $\mathrm{Fe}(\mathrm{II})$ at the surface, fast transfer of charge to neighboring Fe(III) sites, and detachment of $\mathrm{Fe}(\mathrm{III}) \mathrm{DFOB}$. The ratio of $\left[{ }^{57} \mathrm{Fe}\right]_{\text {tracer,diss. }}$ to $\left[{ }^{56} \mathrm{Fe}\right]^{*}$ diss. corresponds to the fraction of the charge that resides on ${ }^{56} \mathrm{Fe}$ and ${ }^{57} \mathrm{Fe}$ at the $\mathrm{Lp}$ surface. The model fits indicate that ${ }^{56} \mathrm{Fe}(\mathrm{II})$ is $4.0-4.5$ times more abundant than ${ }^{57} \mathrm{Fe}$ (II) at the surface.

Assuming equal probabilities for charge distribution over available surface sites, this would mean that each unit of negative charge is on average distributed over 4.0-4.5 Fe sites. The release of ${ }^{57} \mathrm{Fe}$ at $\mathrm{pH} 7.0$ with $\mathrm{DFOB}$ occurred more slowly than at $\mathrm{pH} 6.0$ with EDTA as reported in our recent study with EDTA, indicating that charge distribution at $\mathrm{pH} 7.0$ before and during dissolution was more extensive than at $\mathrm{pH}$ 6.0. This can be rationalized by the nearly complete adsorption of $\mathrm{Fe}(\mathrm{II})$ at $\mathrm{pH} 7.0$, compared to only around $20 \%$ adsorption at $\mathrm{pH}$ 6.0. Even after dissolution of $38 \mu \mathrm{M}$ Fe(III) with DFOB, which is over four times the concentration of the fitted concentration of surface sites, we observed the reappearance of only $85-90 \%$ of added ${ }^{57} \mathrm{Fe}$ in solution. The model accounts for this by "dilution" of ${ }^{57} \mathrm{Fe}$ sites through the regeneration of predominantly ${ }^{56} \mathrm{Fe}$ surface sites from the bulk solid.

\section{ENVIRONMENTAL SIGNIFICANCE}

We found that in anoxic carbonate-buffered suspensions at $\mathrm{pH}$ 7.0, micromolar concentrations of added Fe(II) can accelerate the rates of $\mathrm{Lp}$ dissolution with DFOB up to a factor of 60 under anoxic conditions. Since aquatic systems are generally carbonate-buffered, it is likely that the acceleration of ligandcontrolled dissolution by traces of $\mathrm{Fe}$ (II) in natural waters would be at least as large as observed in laboratory experiments with Good's buffers. Our results are most relevant for soils and surface waters with $\mathrm{pH}$ values around 7 . Recent analytical developments have demonstrated that strong organic ligands found in the ocean contain compounds with structures similar to DFOB. ${ }^{53}$ Thus, the mechanisms identified for DFOB may also be important for ligands secreted by marine biota.

The interfacial $\mathrm{Fe}(\mathrm{II}) / \mathrm{Fe}$ (III) ET plays a crucial role in numerous natural processes, for example in $\mathrm{Fe}$ cycling and bioavailability, and in trace element incorporation and release. We show that rates for ET and isotope exchange during 
sorption and accelerated dissolution are very different for $\mathrm{Lp}$ and Gt, presumably reflecting the difference in structure and mineralogy. We suggest that future studies are extended to different Fe(III)(oxyhydr)oxide phases. Fe(III) phases formed under natural conditions are often less crystalline and contain co-precipitated cations and anions. ${ }^{54}$ Future work should test if these phases are also susceptible to $\mathrm{Fe}(\mathrm{II})$-accelerated dissolution. The application of ${ }^{57} \mathrm{Fe}$ as a tracer in dissolution experiments can provide relevant information about the fate of $\mathrm{Fe}(\mathrm{II})$, and the mobility and effect of negative charge on the dissolution of $\mathrm{Fe}(\mathrm{III})$ phases in the presence of ligands and low concentrations of $\mathrm{Fe}(\mathrm{II})$.

\section{ASSOCIATED CONTENT}

\section{S Supporting Information}

The Supporting Information is available free of charge at https://pubs.acs.org/doi/10.1021/acs.est.9b04235.

List of chemicals; list of experiments and experimental conditions; kinetic model with full list of reactions; speciation of $\mathrm{Fe}(\mathrm{II})$ in carbonate-buffered suspensions; speciation of $\mathrm{Fe}$ (II) and control experiments with phenanthroline; ${ }^{57} \mathrm{Fe}$ isotope exchange experiments in carbonate- and MOPS-buffered suspensions; Gt dissolution; speciation of $\mathrm{Fe}$ and DFOB; and output of kinetic model with different charge distributions between ${ }^{57} \mathrm{Fe}$ and ${ }^{56} \mathrm{Fe}$ surface sites (PDF)

\section{AUTHOR INFORMATION}

\section{Corresponding Author}

*E-mail: stephan.hug@eawag.ch.

\section{ORCID $\odot$}

Jagannath Biswakarma: 0000-0002-5200-0729

Kyounglim Kang: 0000-0003-3719-5166

Walter D. C. Schenkeveld: 0000-0002-1531-0939

Janet G. Hering: 0000-0002-0865-1946

Stephan J. Hug: 0000-0001-9197-3470

\section{Present Address}

${ }^{\perp}$ Copernicus Institute of Sustainable Development, Faculty of Geosciences, Utrecht University, Princetonlaan 8A, 3584 CB Utrecht, The Netherlands (W.D.C.S.).

\section{Notes}

The authors declare no competing financial interest.

\section{ACKNOWLEDGMENTS}

The authors gratefully acknowledge Thomas Rüttimann (Eawag) for ICP-MS analyses and for technical assistance. This project was financially supported by the Swiss National Science Foundation under contracts No. 200021L_150150 "Synergistic effects of redox processes and ligand-controlled dissolution of iron(hydr)oxide phases" Mathematics, Natural sciences and Engineering (Division II). S.M.K., W.D.C.S., and K.K. were supported by the Austrian Science Fund (FWF, Grant No. I 1528-N19).

\section{REFERENCES}

(1) Watteau, F.; Berthelin, J. Microbial Dissolution of Iron and Aluminum from Soil Minerals - Efficiency and Specificity of Hydroxamate Siderophores Compared to Aliphatic-Acids. Eur. J. Soil Biol. 1994, 30, 1-9.
(2) Hersman, L.; Maurice, P.; Sposito, G. Iron acquisition from hydrous Fe(III)-oxides by an aerobic Pseudomonas sp. Chem. Geol. 1996, 132, 25-31.

(3) Kraemer, S. M.; Hering, J. G. Influence of solution saturation state on the kinetics of ligand-controlled dissolution of oxide phases. Geochim. Cosmochim. Acta 1997, 61, 2855-2866.

(4) Neubauer, U.; Furrer, G.; Schulin, R. Heavy metal sorption on soil minerals affected by the siderophore desferrioxamine $\mathrm{B}$ : the role of $\mathrm{Fe}(\mathrm{III})$ (hydr)oxides and dissolved Fe(III). Eur. J. Soil Sci. 2002, $53,45-55$.

(5) Cervini-Silva, J.; Sposito, G. Steady-State Dissolution Kinetics of Aluminum-Goethite in the Presence of Desferrioxamine-B and Oxalate Ligands. Environ. Sci. Technol. 2002, 36, 337-342.

(6) Kearns, J. P.; Cervini-Silva, J.; Banfield, J. F. Siderophores may simultaneously influence iron and phosphorus bioavailability in soils. Geochim. Cosmochim. Acta 2004, 68, A395.

(7) Kraemer, S. M. Iron oxide dissolution and solubility in the presence of siderophores. Aquat. Sci. 2004, 66, 3-18.

(8) Kraemer, S. M.; Butler, A.; Borer, P.; Cervini-Silva, J. Siderophores and the dissolution of iron-bearing minerals in marine systems. Rev. Mineral. Geochem. 2005, 59, 53-84.

(9) Kraemer, S. M.; Crowley, D. E.; Kretzschmar, R. Geochemical aspects of phytosiderophore-promoted iron acquisition by plants. $A d v$. Agron. 2006, 91, 1-46.

(10) Zhong, L.; Yang, J.; Liu, L.; Li, X. Desferrioxamine-B promoted dissolution of an Oxisol and the effect of low-molecular-weight organic acids. Biol. Fert. Soil 2013, 49, 1077-1083.

(11) Colombo, C.; Palumbo, G.; He, J. Z.; Pinton, R.; Cesco, S. Review on iron availability in soil: Interaction of Fe minerals, plants, and microbes. Biol. Fertil. Soils 2014, 14, 538-548.

(12) Schenkeveld, W. D. C.; Oburger, E.; Gruber, B.; Schindlegger, Y.; Hann, S.; Puschenreiter, M.; Kraemer, S. M. Metal mobilization from soils by phytosiderophores - experiment and equilibrium modeling. Plant Soils 2014, 383, 59-71.

(13) Schenkeveld, W. D. C.; Schindlegger, Y.; Oburger, E.; Puschenreiter, M.; Hann, S.; Kraemer, S. M. Geochemical Processes Constraining Iron Uptake in Strategy II Fe Acquisition. Environ. Sci. Technol. 2014, 48, 12662-12670.

(14) Schenkeveld, W. D. C.; Kimber, R. L.; Walter, M.; Oburger, E.; Puschenreiter, M.; Kraemer, S. M. Experimental considerations in metal mobilization from soil by chelating ligands: The influence of soil-solution ratio and pre-equilibration - A case study on $\mathrm{Fe}$ acquisition by phytosiderophores. Sci. Total Environ. 2017, 579, $1831-1842$.

(15) Cheah, S. F.; Kraemer, S. M.; Cervini-Silva, J.; Sposito, G. Steady-state dissolution kinetics of goethite in the presence of desferrioxamine B and oxalate ligands: Implications for the microbial acquisition of iron. Chem. Geol. 2003, 198, 63-75.

(16) Reichard, P. U.; Kretzschmar, R.; Kraemer, S. M. Dissolution mechanisms of goethite in the presence of siderophores and organic acids. Geochim. Cosmochim. Acta 2007, 71, 5635-5650.

(17) Loring, J. S.; Simanova, A. A.; Persson, P. Highly mobile iron pool from a dissolution-readsorption process. Langmuir 2008, 24, $7054-7057$.

(18) Lemanceau, P.; Bauer, P.; Kraemer, S.; Briat, J. F. Iron dynamics in the rhizosphere as a case study for analyzing interactions between soils, plants and microbes. Plant Soils 2009, 321, 513-535.

(19) Sandy, M.; Butler, A. Microbial iron acquisition: Marine and terrestrial siderophores. Chem. Rev. 2009, 109, 4580-4595.

(20) Dehner, C. A.; Awaya, J. D.; Maurice, P. A.; DuBois, J. L. Roles of Siderophores, Oxalate, and Ascorbate in Mobilization of Iron from Hematite by the Aerobic Bacterium Pseudomonas mendocina. Appl. Environ. Microbiol. 2010, 76, 2041-2048.

(21) Akafia, M. M.; Harrington, J. M.; Bargar, J. R.; Duckworth, O. W. Metal oxyhydroxide dissolution as promoted by structurally diverse siderophores and oxalate. Geochim. Cosmochim. Acta 2014, $141,258-269$. 
(22) Hersman, L.; Lloyd, T.; Sposito, G. Siderophore-Promoted Dissolution of Hematite. Geochim. Cosmochim. Acta 1995, 59, 33273330.

(23) Yoshida, T.; Hayashi, K.; Ohmoto, H. Dissolution of iron hydroxides by marine bacterial siderophore. Chem. Geol. 2002, 184, $1-9$.

(24) Stewart, A. G.; Hudson-Edwards, K. A.; Dubbin, W. E. Mechanisms of goethite dissolution in the presence of desferrioxamine B and Suwannee River fulvic acid at $\mathrm{pH}$ 6.5. Geochim. Cosmochim. Acta 2013, 115, 1-14.

(25) Wang, Z.; Schenkeveld, W. D. C.; Kraemer, S. M.; Giammar, D. E. Synergistic Effect of Reductive and Ligand-Promoted Dissolution of Goethite. Environ. Sci. Technol. 2015, 49, 7236-7244.

(26) Schenkeveld, W. D. C.; Wang, Z. M.; Giammar, D. E.; Kraemer, S. M. Synergistic Effects between Biogenic Ligands and a Reductant in Fe Acquisition from Calcareous Soil. Environ. Sci. Technol. 2016, 50, 6381-6388.

(27) Biswakarma, J.; Kang, K.; Borowski, S. C.; Schenkeveld, W. D. C.; Kraemer, S. M.; Hering, J. G.; Hug, S. J. Fe(II)-Catalyzed LigandControlled Dissolution of Iron(hydr)oxides. Environ. Sci. Technol. 2019, 53, 88-97.

(28) Kang, K.; Schenkeveld, W. D. C.; Biswakarma, J.; Borowski, S. C.; Hug, S. J.; Hering, J. G.; Kraemer, S. M. Low Fe(II) Concentrations Catalyze the Dissolution of Various Fe(III) (hydr)oxide Minerals in the Presence of Diverse Ligands and over a Broad pH Range. Environ. Sci. Technol. 2019, 53, 98-107.

(29) Williams, A. G. B.; Scherer, M. M. Spectroscopic evidence for $\mathrm{Fe}(\mathrm{II})-\mathrm{Fe}(\mathrm{III})$ electron transfer at the iron oxide-water interface. Environ. Sci. Technol. 2004, 38, 4782-4790.

(30) Pedersen, H. D.; Postma, D.; Jakobsen, R.; Larsen, O. Fast transformation of iron oxyhydroxides by the catalytic action of aqueous Fe(II). Geochim. Cosmochim. Acta 2005, 69, 3967-3977.

(31) Larese-Casanova, P.; Scherer, M. M. Fe(II) sorption on hematite: New insights based on spectroscopic measurements. Environ. Sci. Technol. 2007, 41, 471-477.

(32) Yanina, S. V.; Rosso, K. M. Linked reactivity at mineral-water interfaces through bulk crystal conduction. Science 2008, 320, 218222.

(33) Handler, R. M.; Beard, B. L.; Johnson, C. M.; Scherer, M. M. Atom exchange between aqueous $\mathrm{Fe}(\mathrm{II})$ and goethite: $\mathrm{An} \mathrm{Fe}$ isotope tracer study. Environ. Sci. Technol. 2009, 43, 1102-1107.

(34) Catalano, J. G.; Fenter, P.; Park, C.; Zhang, Z.; Rosso, K. M. Structure and oxidation state of hematite surfaces reacted with aqueous $\mathrm{Fe}(\mathrm{II})$ at acidic and neutral $\mathrm{pH}$. Geochim. Cosmochim. Acta 2010, 74, 1498-1512.

(35) Gorski, C. A.; Handler, R. M.; Beard, B. L.; Pasakarnis, T.; Johnson, C. M.; Scherer, M. M. Fe Atom Exchange between Aqueous Fe2+ and Magnetite. Environ. Sci. Technol. 2012, 46, 12399-12407.

(36) Latta, D. E.; Gorski, C. A.; Scherer, M. M. Influence of Fe2+catalysed iron oxide recrystallization on metal cycling. Biochem. Soc. Trans. 2012, 40, 1191-1197.

(37) Handler, R. M.; Frierdich, A. J.; Johnson, C. M.; Rosso, K. M.; Beard, B. L.; Wang, C.; Latta, D. E.; Neumann, A.; Pasakarnis, T.; Premaratne, W. A. P. J.; Scherer, M. M. Fe(II)-catalyzed recrystallization of goethite revisited. Environ. Sci. Technol. 2014, 48, 11302-11311.

(38) Frierdich, A. J.; Helgeson, M.; Liu, C. S.; Wang, C. M.; Rosso, K. M.; Scherer, M. M. Iron Atom Exchange between Hematite and Aqueous Fe(II). Environ. Sci. Technol. 2015, 49, 8479-8486.

(39) Joshi, P.; Gorski, C. A. Anisotropic Morphological Changes in Goethite during Fe2+-Catalyzed Recrystallization. Environ. Sci. Technol. 2016, 50, 7315-7324.

(40) Zarzycki, P.; Rosso, K. M. Stochastic Simulation of Isotopic Exchange Mechanisms for Fe(II)-Catalyzed Recrystallization of Goethite. Environ. Sci. Technol. 2017, 51, 7552-7559.

(41) Braun, W.; H, J. T.; Kahaner, D. K. Acuchem: A computer program for modeling complex chemical reaction systems. Int. J. Chem. Kinet. 1988, 20, 51-62.
(42) Appelo, C. A. J.; Van der Weiden, M. J. J.; Tournassat, C.; Charlet, L. Surface complexation of ferrous iron and carbonate on ferrihydrite and the mobilization of arsenic. Environ. Sci. Technol. 2002, 36, 3096-3103.

(43) Buchholz, A.; Laskov, C.; Haderlein, S. B. Effects of Zwitterionic Buffers on Sorption of Ferrous Iron at Goethite and Its Oxidation by CCl4. Environ. Sci. Technol. 2011, 45, 3355-3360.

(44) Borer, P. M.; Sulzberger, B.; Reichard, P.; Kraemer, S. M. Effect of siderophores on the light-induced dissolution of colloidal iron(III) (hydr)oxides. Mar. Chem. 2005, 93, 179-193.

(45) Borer, P.; Hug, S. J.; Sulzberger, B.; Kraemer, S. M.; Kretzschmar, R. ATR-FTIR spectroscopic study of the adsorption of desferrioxamine $\mathrm{B}$ and aerobactin to the surface of lepidocrocite (gamma-FeOOH). Geochim. Cosmochim. Acta 2009, 73, 4661-4672.

(46) Borer, P.; Sulzberger, B.; Hug, S. J.; Kraemer, S. M.; Kretzschmar, R. Photoreductive Dissolution of Iron(III) (Hydr)oxides in the Absence and Presence of Organic ligands: Experimental Studies and Kinetic Modeling. Environ. Sci. Technol. 2009, 43, 18641870.

(47) Borer, P.; Kraemer, S. M.; Sulzberger, B.; Hug, S. J.; Kretzschmar, R. Photodissolution of lepidocrocite (gamma$\mathrm{FeOOH}$ ) in the presence of desferrioxamine $\mathrm{B}$ and aerobactin. Geochim. Cosmochim. Acta 2009, 73, 4673-4687.

(48) Soltis, J. A.; Schwartzberg, A. M.; Zarzycki, P.; Penn, R. L.; Rosso, K. M.; Gilbert, B. Electron Mobility and Trapping in Ferrihydrite Nanoparticles. ACS Earth Space Chem. 2017, 1, 216-226.

(49) Kim, D.; Duckworth, O. W.; Strathmann, T. J. Reactions of aqueous iron-DFOB (desferrioxamine B) complexes with flavin mononucleotide in the absence of strong iron(II) chelators. Geochim. Cosmochim. Acta 2010, 74, 1513-1529.

(50) Joshi, P.; Fantle, M. S.; Larese-Casanova, P.; Gorski, C. A. Susceptibility of Goethite to Fe2+-Catalyzed Recrystallization over Time. Environ. Sci. Technol. 2017, 51, 11681-11691.

(51) Taylor, S. D.; Liu, J.; Zhang, X.; Arey, B. W.; Kovarik, L.; Schreiber, D. K.; Perea, D. E.; Rosso, K. M. Visualizing the iron atom exchange front in the $\mathrm{Fe}(\mathrm{II})$-catalyzed recrystallization of goethite by atom probe tomography. Proc. Natl. Acad. Sci. U.S.A. 2019, 116, 2866-2874.

(52) Frierdich, A. J.; Saxey, D.; Adineh, V.; Fougerouse, D.; Reddy, S.; Rickard, W. D. A.; Sadek, A.; Southall, S. Direct Observation of Nanoparticulate Goethite Recrystallization by Atom Probe Analysis of Isotopic Tracers. Environ. Sci. Technol. 2019, 53, 13126-13135.

(53) Boiteau, R. M.; Mende, D. R.; Hawco, N. J.; McIlvin, M. R.; Fitzsimmons, J. N.; Saito, M. A.; Sedwick, P. N.; DeLong, E. F.; Repeta, D. J. Siderophore-based microbial adaptations to iron scarcity across the eastern Pacific Ocean. Proc. Natl. Acad. Sci. U.S.A. 2016, $113,14237-14242$.

(54) Senn, A.-C.; Kaegi, R.; Hug, S. J.; Hering, J. G.; Mangold, S.; Voegelin, A. Composition and structure of $\mathrm{Fe}(\mathrm{III})$-precipitates formed by $\mathrm{Fe}(\mathrm{II})$ oxidation in water at near-neutral $\mathrm{pH}$ : Interdependent effects of phosphate, silicate and Ca. Geochim. Cosmochim. Acta 2015, 162, 220-246. 